\title{
RESEARCH
}

Open Access

\section{Effector function of anti-pyroglutamate-3 $A \beta$ antibodies affects cognitive benefit, glial activation and amyloid clearance in Alzheimer's-like mice}

Helen Crehan ${ }^{1,2}$, Bin Liu ${ }^{1,2}$, Martin Kleinschmidt ${ }^{3,4}$, Jens-Ulrich Rahfeld ${ }^{3,4}$, Kevin X. Le', Barbara J. Caldarone ${ }^{2,5}$, Jeffrey L. Frost ${ }^{1}$, Thore Hettmann ${ }^{3}$, Birgit Hutter-Paier ${ }^{6}$, Brian O'Nuallain ${ }^{1,2}$, Mi-Ae Park ${ }^{2,7}$, Marcelo F. DiCarli ${ }^{2,7}$, Inge Lues ${ }^{3}$, Stephan Schilling ${ }^{3,4}$ and Cynthia A. Lemere ${ }^{1,2^{*}}$ (D)

\begin{abstract}
Background: Pyroglutamate-3 A $(p G l u-3 A \beta$ ) is an N-terminally truncated and post-translationally modified $A \beta$ species found in Alzheimer's disease (AD) brain. Its increased peptide aggregation propensity and toxicity make it an attractive emerging treatment strategy for AD. We address the question of how the effector function of an antipGlu-3 A $\beta$ antibody influences the efficacy of immunotherapy in mouse models with AD-like pathology.

Methods: We compared two different immunoglobulin (Ig) isotypes of the same murine anti-pGlu-3 A $\mathrm{mAb}$ $(07 / 1 \mathrm{lgG} 1$ and $07 / 2 \mathrm{a} \lg \mathrm{G} 2 \mathrm{a})$ and a general N-terminal $A \beta \mathrm{mAb}(3 \mathrm{~A} 1 \mathrm{lgG} 1)$ for their ability to clear $A \beta$ and protect cognition in a therapeutic passive immunotherapy study in aged, plaque-rich APP SWE/PS1 $\Delta$ E9 transgenic (Tg) mice. We also compared the ability of these antibodies and a CDC-mutant form of 07/2a (07/2a-k), engineered to avoid complement activation, to clear $A \beta$ in an ex vivo phagocytosis assay and following treatment in $\mathrm{APP}_{\mathrm{SL}} \mathrm{xhQC}$ double $\mathrm{Tg}$ mice, and to activate microglia using longitudinal microPET imaging with TSPO-specific ${ }^{18} \mathrm{~F}-\mathrm{GE} 180$ tracer following a single bolus antibody injection in young and old Tg mice.

Results: We demonstrated significant cognitive improvement, better plaque clearance, and more plaque-associated microglia in the absence of microhemorrhage in aged APP SWE/PS1 $\triangle E 9$ Tg mice treated with 07/2a, but not 07/1 or $3 \mathrm{~A} 1$, compared to PBS in our first in vivo study. All mAbs cleared plaques in an ex vivo assay, although 07/2a promoted the highest phagocytic activity. Compared with 07/2a, 07/2a-k showed slightly reduced affinity to Fcy receptors CD32

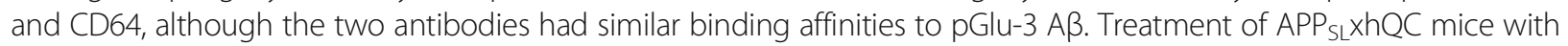
07/2a and 07/2a-k mAbs in our second in vivo study showed significant plaque-lowering with both mAbs. Longitudinal ${ }^{18} \mathrm{~F}$-GE180 microPET imaging revealed different temporal patterns of microglial activation for 3A1, 07/1, and 07/2a mAbs and no difference between 07/2a-k and PBS-treated Tg mice.

(Continued on next page)
\end{abstract}

\footnotetext{
* Correspondence: clemere@bwh.harvard.edu

${ }^{1}$ Ann Romney Center for Neurologic Diseases, Brigham and Women's

Hospital, Hale BTM 9002S, 60 Fenwood Rd, Boston, MA 02115, USA

${ }^{2}$ Harvard Medical School, Boston, MA, USA

Full list of author information is available at the end of the article
}

(c) The Author(s). 2020 Open Access This article is distributed under the terms of the Creative Commons Attribution 4.0 International License (http://creativecommons.org/licenses/by/4.0/), which permits unrestricted use, distribution, and reproduction in any medium, provided you give appropriate credit to the original author(s) and the source, provide a link to the Creative Commons license, and indicate if changes were made. The Creative Commons Public Domain Dedication waiver (http://creativecommons.org/publicdomain/zero/1.0/) applies to the data made available in this article, unless otherwise stated. 


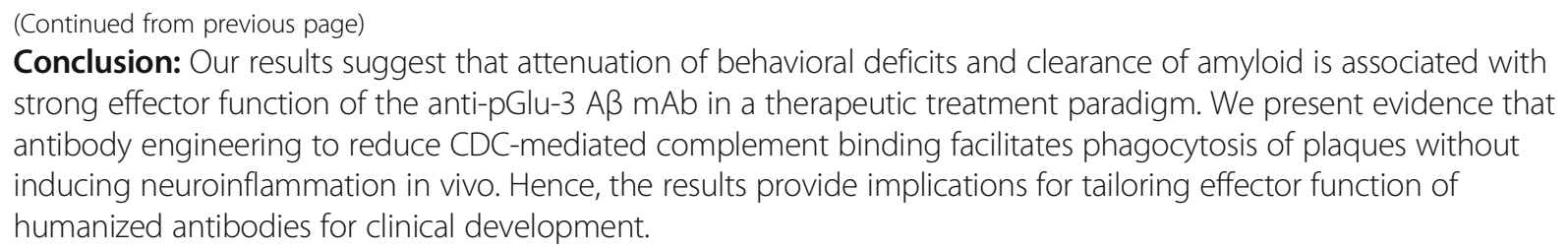

Keywords: Pyroglutamate-3 amyloid- $\beta$, Immunotherapy, APP SWE/PS1 1 E9, Phagocytosis, Microhemorrhage, microPET

\section{Background}

Alzheimer's disease (AD) is the most common form of dementia, with global prevalence of this devastating disease estimated at 50 million people and predicted to triple by 2050 [1]. The pathological hallmarks of $\mathrm{AD}$ include amyloid-beta $(\mathrm{A} \beta)$ plaques and neurofibrillary tangles. Strong genetic and pathological evidence indicates the "amyloid hypothesis" as a central contributor of early AD pathogenesis [2].

On the basis of the amyloid hypothesis, removal of $A \beta$ aggregates by immunotherapy has been suggested as a treatment option to slow or halt AD [3]. Peripherally administered anti-A $\beta$ antibodies are able to access the CNS to reduce the extent of plaque deposition through Fc-mediated phagocytosis [4, 5]. Following the initial failures of active and passive immunotherapies after the onset of clinical symptoms, a Phase $1 \mathrm{~b}$ study of an antiA $\beta$ monoclonal antibody, aducanumab, provided promising results with regard to amyloid lowering and cognitive readouts [6]. Similar to some other anti-amyloid antibodies, aducanumab treatment was accompanied by amyloid-related imaging abnormalities (ARIA), imaging abnormalities indicating mostly asymptomatic and transient side effects due to vascular edema. Biogen halted all aducanumab clinical trials in March 2019 after an interim futility analysis of half of the participants predicted that there would be no clinical benefit in patients with prodromal or mild AD (press release March 21, 2019; AD/PD 2019, Lisbon). In October 2019, Biogen announced that upon analysis of the full data set of all participants, aducanumab reached its primary endpoint of clinical benefit (CDR-SB) in a large Phase III clinical trial (EMERGE), and while not significant in another large Phase III (ENGAGE) study, post hoc analysis showed slowing of cognitive decline for those in the high dose treatment group (press release Oct 22, 2019; CTAD 2019, San Diego). Both studies showed dose- and timedependent lowering of cerebral amyloid. Biogen announced it will seek Federal Drug Administration approval in early 2020. If approved, aducanumab would be the first-ever disease modifying treatment for mild cognitive impairment and early-stage Alzheimer's disease.

As with aducanumab, most of the antibodies currently under clinical development are immunoglobulin G (IgG1) molecules. Immunoglobulin G (IgG) is the major class of immunoglobulins in human serum, and the Fc portion of this antibody determines the IgG isotype and, as such, mediates the effector function such as phagocytosis, antibodydependent cellular toxicity (ADCC), and complementdependent cytotoxicity (CDC) [7]. Human IgG1 and IgG3 usually elicit a strong effector function via $\mathrm{Fcy}$ receptors [8]. IgG1 accounts for the highest abundance of immunoglobulin in the blood and has a longer half-life; thus, it has been the preferred candidate for engineering an antibody for therapeutic use $[9,10]$. However, the strong effector function of IgG1 molecules might trigger neuroinflammation and ARIAs, as observed with aducanumab and other anti-amyloid antibodies, including Eli Lilly's anti-pGlu3 A $\beta$ antibody, donanemab which is currently in clinical trials. Other monoclonal antibodies, such as crenezumab [11], were generated on an IgG4 backbone in order to reduce ADCC and CDC functionality. However, two large Phase III crenezumab clinical trials in early $\mathrm{AD}$ were terminated earlier this year due to an interim analysis that suggested that treatment would not likely slow cognitive decline in patients with prodromal to mild AD. A Phase II secondary prevention study of crenezumab treatment in amyloidpositive cognitively normal subjects with the presenilin 1 E280A mutation that causes early onset familial AD is currently underway in Colombia through the Alzheimer's Prevention Initiative. These setbacks suggest that the interplay between antibody epitope specificity and effector function requires a thorough analysis, which was one of our major goals of this current study.

In the light of these previous findings, we wanted to address the role of the IgG isotype for efficacy and potential side effects for an anti-pyroglutamate-3 (pGlu-3) A $\beta$ antibody, 07/1 [12]. This antibody targets a truncated and Nterminally modified form $A \beta 40 / 42$, which is present in the intracellular, extracellular, and vascular deposits in $\mathrm{AD}$ and Down syndrome (DS) brain tissue [13-16]. The formation of pGlu-3 A $\beta$ results in altered biochemical properties such as elevated hydrophobicity, higher predisposition to aggregate and increased toxicity [17-22]. We previously reported that preventive immunization with the murine anti-pGlu-3 A $\beta$ IgG1 07/1 mAb improved cognition and reduced plaques in young $\mathrm{APP}_{\mathrm{SWE}} / \mathrm{PS} 1 \triangle \mathrm{E} 9 \mathrm{Tg}$ mice when administered at an early stage of plaque deposition [12]. (Note that 
human and mouse IgG isotypes are not directly homologous: Human IgG1 is comparable with mouse IgG2a due to similar ability to bind to $\mathrm{Fcy}$ receptors and activate the complement system [23]). We also reported in a small pilot study that $07 / 1$ reduced plaque deposition with a murine anti-pGlu3 $\mathrm{A} \beta$ IgG1 $\mathrm{mAb}$ in aged $\mathrm{APP}_{\mathrm{SWE}} / \mathrm{PS} 1 \Delta \mathrm{E} 9 \mathrm{Tg}$ mice; however, biochemical $A \beta$ levels were unchanged and cognition was not examined [24]. In the present study, we compared the effect of therapeutic immunization with the 07 anti-pGlu3 $A \beta$, of either murine IgG1 or IgG2a subtype, known as $07 / 1$ and $07 / 2$ a respectively, and a general Nterminal $\mathrm{A} \beta \mathrm{mAb}$ (3A1 IgG1) on behavior, $\mathrm{A} \beta$ clearance, and microglia in aged $\mathrm{APP}_{\mathrm{SWE}} / \mathrm{PS} 1 \triangle \mathrm{E} 9 \mathrm{Tg}$ mice. In subsequent studies, a CDC mutation (K322A) was engineered into the murine $07 / 2 \mathrm{a}$ antibody to inhibit complement activation $(07 / 2 a-k m A b)$. The effector functions of these antiA $\beta$ mAbs were further examined in a double transgenic hAPPSLxhQC mouse model and an ex vivo phagocytosis assay. Lastly, the microglial activation profiles at baseline, 3 days, and 30 days after a single bolus injection of PBS or antibody were investigated by longitudinal in vivo microPET imaging using a second-generation, highly specific translocator protein (TSPO) radioligand, ${ }^{18} \mathrm{~F}$-GE180 $[25,26]$ in both 4-month (mo)-old and 16mo-old $\mathrm{APP}_{\mathrm{SWE}} / \mathrm{PS} 1 \triangle \mathrm{E} 9 \mathrm{Tg}$ mice. In summary, this nonclinical study was designed to provide information regarding the effector function responsible for efficacy and potential side effects of anti-pGlu-3 $A \beta$ mAb immunotherapy.

\section{Methods}

\section{Animals}

A passive immunization study was conducted in male, plaque-rich $\mathrm{APP}_{\mathrm{SWE}} / \mathrm{PS} 1 \triangle \mathrm{E} 9$ transgenic $(\mathrm{Tg})$ mice on a C57BL/6 J background starting at $\sim 12$ mo of age. $\mathrm{APP}_{\mathrm{SWE}} / \mathrm{PS} 1 \triangle \mathrm{E} 9$ mice express two human genes of familial AD, the APP ${ }^{\mathrm{K} 594 \mathrm{~N} / \mathrm{M} 595 \mathrm{~L}}$ Swedish and Presenilin 1 delta E9 (PS1 $\triangle \mathrm{E} 9$ ) (deletion of exon 9) under a mouse prion promoter [27]. Original Tg breeders were obtained from The Jackson Laboratory (Bar Harbor, ME) and were maintained in our colony by crossing male $\mathrm{APP}_{\text {SWE }} / \mathrm{PS} 1 \Delta \mathrm{E} 9 \mathrm{Tg}$ mice with female C57BL/6 J mice. All animal protocols were approved by the Harvard Medical Area Standing Committee on Animals, and studies were performed in accordance with all state and federal regulations. The Harvard Medical School animal management program is accredited by the Association for the Assessment and Accreditation of Laboratory Animal Care International and meets all National Institutes of Health standards as demonstrated by an approved Assurance of Compliance (A3431-01) filed at the Office of Laboratory Animal Welfare.

Another amyloid mouse model, hAPPSL;hQC mice, which are double transgenic for the human APP gene containing Swedish and London mutation and human glutaminyl cyclase (QC) [19], were also used to assess the efficacy of $07 / 2 a$ IgG2a and 07/2a-k IgG2a antibodies. Animals were housed in individually ventilated cages on standardized rodent bedding supplied by Rettenmaier Austria GmbH \& Co.KG (Vienna, Austria). Mice were kept in the Association for Assessment and Accreditation of Laboratory Animal Care-accredited animal facility of QPS Austria GmbH (previously JSW Lifesciences, $\mathrm{GmbH}$, Grambach, Austria). Animal studies conformed to the Austrian guidelines for the care and use of laboratory animals and were approved by the Styrian government, Austria.

\section{Antibodies for immunotherapy and the ex vivo phagocytosis assay}

Multiple murine anti-pyroglutamate- $3 \mathrm{~A} \beta$ antibodies of different IgG isotypes were used in these studies, all of which were generated and provided by Vivoryon Therapeutics AG (formerly Probiodrug AG, Halle, Germany). These include murine IgG1 (07/1) and IgG2a (07/2a) isotype versions of the same 07 monoclonal antibody targeting the $\mathrm{N}$-terminally truncated and modified (by cyclization by $\mathrm{QC}$ ) $\mathrm{A} \beta$. In an effort to avoid inflammation and possibly ARIA, a CDC-mutant (K322A) version of the murine IgG2a isotype antibody (07/2a-k), which exhibits less complement activation due to its inability to bind $\mathrm{C} 1 \mathrm{q}$, was engineered and provided by Vivoryon Therapeutics AG. The respective IgG1 isotype control antibody was purchased from Thermo Fisher Scientific; the IgG2a isotype control was produced by Fraunhofer IZI-MWT.

In addition, the following studies included a purified $\beta$-amyloid 1-15 monoclonal antibody raised against dityrosine cross-linked human $\mathrm{A} \beta 1-40$, named $3 \mathrm{~A} 1$, which was kindly provided by Dr. Brian O'Nuallain and is now commercially available from BioLegend. 3A1 does not recognize pGlu3 A $\beta$ or APP [12].

\section{Immunotherapy treatment, behavioral testing, and euthanasia}

A total of 80 male 12-mo-old $\mathrm{APP}_{\mathrm{SWE}} / \mathrm{PS} 1 \Delta \mathrm{E} 9$ mice were utilized for the first in vivo study. Prior to the start of immunization, five $\mathrm{APP}_{\mathrm{SWE}} / \mathrm{PS} 1 \Delta \mathrm{E} 9 \mathrm{Tg}$ mice (avg. $12.3 \mathrm{mo} \pm 0.08)$ were sacrificed as baseline controls to assess plaque burden at commencement of treatment. The remaining 75 mice were divided into four groups and received the following treatments: $250 \mu \mathrm{l}$ sterile phosphate buffered saline (PBS) $(n=14$; originally $n=15$ but one removed due to incorrect genotype); avg. 12.2 mo \pm 0.77$), 300 \mu \mathrm{g} 3 \mathrm{~A} 1$, a general $\mathrm{A} \beta \operatorname{IgG} 1 \mathrm{mAb}(n=15$; avg. $12.2 \mathrm{mo} \pm 0.8), 300 \mu \mathrm{g} 07 / 1$, a pGlu-3 A $\beta$ IgG1 mAb ( $n=15$; avg. $12.2 \mathrm{mo} \pm 0.55$ ) or $300 \mu \mathrm{g} 07 / 2 \mathrm{a}$, a pGlu-3 $\mathrm{A} \beta$ IgG2a mAb $(n=15$; avg. $12.3 \mathrm{mo} \pm 0.35)$. A group of 
age- and gender-matched wildtype (Wt) littermates were injected with $250 \mu \mathrm{l}$ sterile PBS ( $n=15$; avg. $12.3 \mathrm{mo} \pm$ 0.91 ) and served as behavioral controls. Mice were treated weekly with a total volume of $250 \mu \mathrm{l}$ antibody or PBS via intraperitoneal (i.p) injection for 16 weeks (i.e., from 12 to 16 mo of age).

Behavioral testing of all mice was performed starting at $\sim 15$ mo of age, during which time, mice continued to be treated. Open field (to measure spontaneous locomotor activity and anxiety), contextual fear conditioning (CFC) (to measure associative learning and fear memory), and water T-maze (to assess spatial learning and memory) tests were performed as described [12]. Mice were euthanized at 16 mo of age, 1 week after the last treatment.

An additional immunotherapy study with 29 mice in total was conducted in 8-mo-old hAPPSL;hQC mice examining the in vivo effects of $07 / 2 a$ IgG2a and 07/2a-k IgG2a-k. These mice were divided into three groups; PBS vehicle treated $(n=7), 07 / 2 \mathrm{a}(150 \mu \mathrm{g})(n=8), 07 / 2 \mathrm{a}$ $(500 \mu \mathrm{g})(n=7)$ and $07 / 2 \mathrm{a}-\mathrm{k}(500 \mu \mathrm{g})(n=7)$ and given a weekly i.p injection for 16 weeks.

Mice were euthanized and perfused and brain and plasma were harvested prior to dosing (baseline) or after i.p injections for 16 weeks as previously described in [16] and in Additional file 1 (S1.1).

\section{Histology, image analysis, and ELISA quantification of $A \beta$ and cytokines}

Ten- and 20- $\mu$ m-thick brain sagittal cryosections were cut with a Leica CM1850 cryostat and mounted on Colorfrost Plus slides (Fisher Scientific) or Poly-L-lysinecoated 12-mm glass coverslips (Corning) for immunohistochemistry (IHC) and an ex vivo phagocytosis assay, respectively. Neuropathological analysis of $A \beta$ plaque burden and associated gliosis was carried out as previously described in [16] and in Additional file 1: (S1.2). Fibrillar amyloid was stained with Thioflavin $\mathrm{S}$ dye as previously described in [28] and in Additional file 1: (S1.2). Brain tissue without the cerebellum was homogenized. $A \beta$ and cytokine levels in homogenates were measured by ELISA as outlined in Additional file 1: (S1.3).

\section{Antibody concentration measurements in plasma and brain}

The concentrations of the exogenous antibodies (3A1, $07 / 1$, and $07 / 2 \mathrm{a}$ ) in the brain homogenates and the terminal plasma samples (1 week post-final injection) were measured as described [12], using streptavidin-coated 96-well plates coated in biotinylated $A \beta$ peptide as described in Additional file 1: (S.1.4).

\section{Cell culture}

Primary microglia (PMG) were prepared from the cortices of mouse pups at postnatal day 5 and cultured as described [29, 30]. The murine N9 immortalized microglial cell line was generated by Dr. Paola RicciardiCastagnoli [31] and was kindly provided to us by Dr. Joseph El Khoury (Massachusetts General Hospital) with her permission.

\section{Ex vivo phagocytosis assay}

Aged (20-mo-old), plaque-rich $\mathrm{APP}_{\mathrm{SWE}} / \mathrm{PS} 1 \Delta \mathrm{E} 9$ unfixed mouse brains were gently frozen in liquid nitrogen vapors, sagittally sectioned to $20 \mu \mathrm{m}$, and mounted on 12 $\mathrm{mm}$ round poly-L-lysine-coated cover slips and placed in 24-well tissue culture plates for the PMG cell assay or on $18 \mathrm{~mm}$ round poly-L-lysine-coated cover slips and placed in 12-well tissue culture plates for the N9 cell assay. IHC was performed to confirm tissue was plaquerich with an abundance of pGlu3-A $\beta$ epitope available. Serial sections were incubated with or without antibodies for $1 \mathrm{~h}$ at $37{ }^{\circ} \mathrm{C}$ in $5 \% \mathrm{CO}_{2}$ : anti-pGlu3 $\mathrm{A} \beta$ mAbs 07/1 IgG1, 07/2a IgG2a, and 07/2a-k IgG2a; anti-A $\beta$ 3A1 IgG1; or isotype control IgG1 or isotype control IgG2a, at optimized concentrations of $10 \mu \mathrm{g} / \mathrm{ml}$ for the PMG cell assay or $15 \mu \mathrm{g} / \mathrm{ml}$ for the N9 cell assay. The assay was carried out as described by [32] and in Additional file 1 (S1.5).

\section{Antibody binding to murine $\mathrm{Fcy}$ receptors}

The binding affinities of $07 / 2 \mathrm{a}$ and $07 / 2 \mathrm{a}-\mathrm{k}$ to the murine Fcy receptors (CD16, CD32 and CD64) of J774 macrophages were determined with a conventional ELISA (STC Biologicals, Boston, MA). Recombinant murine CD16, CD32, or CD64 were coated onto plates and bound 07/2a and $07 / 2 \mathrm{a}-\mathrm{k}$ antibodies were detected with an anti-mouse Fab-HRP and quantitated by colorimetric readings. Dissociation constant $\left(\mathrm{K}_{\mathrm{D}}\right)$ values were derived from fitted $\mathrm{IC}_{50}$ values using fixed bottom (0\%) and top (100\%) values, as well as a slope value of 1 .

\section{In vivo PET imaging with ${ }^{18} \mathrm{~F}$-GE180 PET tracer and image analysis}

In vivo microPET imaging was carried out as described in Liu et al. [25] and Additional file 1 (S1.6). Briefly, 4mo- and 16-mo-old male APP/PS1dE9 mice underwent baseline imaging at day 0 followed by an intravenous tail vein injection of $500 \mu \mathrm{g}$ of $3 \mathrm{~A} 1 \mathrm{mAb}, 07 / 1 \mathrm{mAb}, 07 / 2 \mathrm{a}$ $\mathrm{mAb}, 07 / 2 \mathrm{a}-\mathrm{k} \mathrm{mAb}$, or PBS the next day. Follow-up microPET scans were performed 3 days and 30 days post-injection.

\section{Statistics}

With the exception of the behavioral data, statistical analyses were conducted with Prism 5 (GraphPad) using two-way ANOVA with Bonforroni post hoc test for PET imaging analysis or one-way ANOVA with NewmanKeuls post hoc test for all the other group analyses. 
Where indicated, Student's $t$ test was performed for some analyses. For behavioral data, StatView (Version 5.0) was used along with Fisher's PLS. A $p$ value of $<0.05$ was considered significant, and all data are expressed as the mean \pm SEM, unless otherwise stated.

\section{Results}

\section{7/2a mAb treatment significantly improved cognition}

Behavioral testing was initiated at 15 mo of age, approximately 1 month prior to the mice receiving their 16th and final weekly i.p. injection. To control for nonspecific effects on learning and memory, Wt littermate mice received injections of PBS. Following 13 weeks of antibody or PBS administration by i.p injection, mice were placed in an open field arena for measurement of the effects of passive immunotherapy on locomotor activity and anxiety. Total distance traveled and the percent distance traveled in the center of the field was recorded over $60 \mathrm{~min}$. Antibody and PBS-treated $\mathrm{Tg}$ mice were compared to PBS-treated Wt control mice. As expected based on our previous studies, mAb and PBS-injected Tg mice were more active (i.e., more total distance traveled) than Wt PBS-injected mice in the first 30 min of the test session; however, no differences were observed between groups during the last $30 \mathrm{~min}$ of the test session (Fig. 1a). Therefore, mAb treatment did not affect locomotor activity. There was a significant decrease in percent distance traveled in the center of the open field in the Tg PBS-injected mice compared to Wt PBS controls (Fig. 1b) demonstrating a genotype-specific increase in anxiety-like behavior in $\mathrm{APP}_{\mathrm{SWE}} / \mathrm{PS} 1 \Delta \mathrm{E} 9$ mice at 15 mo of age. There was a strong trend for an increased percent distance traveled in the center in the mice treated with $07 / 1 \mathrm{mAb}(p=0.54)$; however, this did not reach significance (Fig. 1b). No differences were observed in the $07 / 2 \mathrm{a}$-treated $\mathrm{Tg}$ mice in the open field testing. CFC testing did not show any differences in fear-associated learning or memory between groups (data not shown).

A water T-maze (WTM) test was used to assess antibody treatment effects on spatial learning and memory and cognitive flexibility in the $\mathrm{APP}_{\mathrm{SWE}} / \mathrm{PS} 1 \triangle \mathrm{E} 9$ mice. The number of correct responses to find the platform made by the PBS-injected Tg mice in the acquisition $(p<0.05)$ and reversal $(p<0.05)$ phases was significantly fewer than what was recorded by the Wt PBS-injected mice demonstrating that the $\mathrm{APP}_{\mathrm{SWE}} / \mathrm{PS} 1 \Delta \mathrm{E} 9$ mice had learning and memory deficits at 15 mo of age (Fig. 1c-e). These deficits were attenuated in the $\mathrm{Tg}$ mice that were treated with $07 / 2 \mathrm{a} \mathrm{mAb}$, which instead showed a significant increase in the percent of correct responses in both the acquisition and reversal tests compared to the PBSinjected Tg control mice (Fig. 1d, e).
$07 / 2 a$ mAb immunotherapy reduced total $A \beta$ plaque burden in aged $\mathrm{APP}_{S W E} / \mathrm{PS} 1 \triangle \mathrm{E} 9 \mathrm{Tg}$ mice

Antibody and PBS-injected mice were sacrificed 1 week following the final injection at 16 mo of age. Tissues were harvested and analyzed for neuropathological and biochemical changes in the CNS and periphery after immunotherapy. In order to assess the potential differences between $07 / 1$ and $07 / 2 \mathrm{a}$ on $\mathrm{A} \beta$ clearance in vivo, we examined mouse brain sections using quantitative immunohistochemistry. $A \beta$ plaque burden was assessed in the brains of the five $\mathrm{APP}_{\mathrm{SWE}} / \mathrm{PS} 1 \triangle \mathrm{E} 9 \mathrm{Tg}$ mice sacrificed at $\sim 12$ mo of age as baseline controls. Immunostaining of fixed brain tissue sections with $07 / 2 \mathrm{~b}$ (pGlu-3 A $\beta$ IgG2b), R1282 (general $A \beta$ ), and 82E1 (A $\beta 1-x)$ showed immunoreactivity (IR) in the hippocampus (HC) and cortex (CTX) (Fig. 2a-h, m-p) in all $\mathrm{APP}_{\text {SWE }} / \mathrm{PS} 1 \Delta \mathrm{E} 9$ Tg mice. Thioflavin S-positive fibrillar amyloid plaques were also observed in the $\mathrm{HC}$ and CTX (Fig. 2i-l). Plaque burden increased from baseline $(12 \mathrm{mo})$ to 16 mo of age.

Pyroglu-3 A $\beta$ IR, measured by $07 / 2 \mathrm{~b} \mathrm{mAb}$, to avoid cross-reactivity between the immunizing mAb $(07 / 1$ or 07/2a) and secondary antibody, was reduced dramatically by $80 \%$ in the HC $(p<0.001)$ and by $81 \%$ in the CTX $(p<0.05)$ of the $07 / 2 \mathrm{a}$-treated $\mathrm{Tg}$ mice compared to PBS-injected mice (Fig. 2a-d, q, u). 07/2a-specific significant reductions were also observed for general $A \beta$ deposition in the $\mathrm{HC}(p<0.05)$ and CTX $(p<0.001)$ where R1282 IR was reduced by $20 \%$ and $51 \%$, respectively, compared to Tg PBS-injected mice (Fig. 2e-h, r, v). Quantification of $A \beta 1-x$ measured by $82 E 1$ IR showed no significant differences between the antibody treatment groups and PBS-injected mice in the $\mathrm{HC}$ (Fig. 2t). However, there was a $35 \%$ reduction $(p<0.05)$ of 82E1 IR in the CTX of 07/2a-treated mice compared to PBS-injected mice (Fig. $2 \mathrm{~m}-\mathrm{p}, \mathrm{x}$ ). Thioflavin Spositive fibrillar amyloid plaques were reduced by $62 \%$ $(p<0.05)$ in $\mathrm{HC}$ and $23 \%(p<0.05)$ in CTX in $07 / 2 \mathrm{a}-$ treated Tg mice compared to PBS controls (Fig. 2i-l, s, $w)$. There were no significant differences in $A \beta$ load as analyzed by one-way ANOVA between PBS-injected Tg mice and $07 / 1$ and $3 \mathrm{~A} 1 \mathrm{mAb}$-treated mice in either the $\mathrm{HC}$ or CTX.

Passive immunization against $A \beta$ in mouse models has demonstrated an increase in cerebral microhemorrhages hypothesized to be due to movement of parenchymal plaques to the vasculature for clearance following antibody treatment $[33,34]$ or possibly because of direct binding of antibodies to existing cerebral amyloid angiopathy [35]. Therefore, we sought to quantify the occurrence of microhemorrhages in this study. Hemosiderin staining was performed for the detection of microhemorrhages across the entirety of three equidistant sagittal cross sections of the mouse brain by three independent 


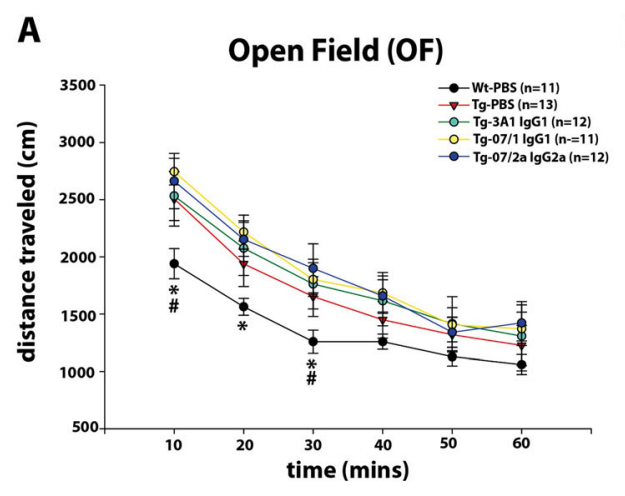

B

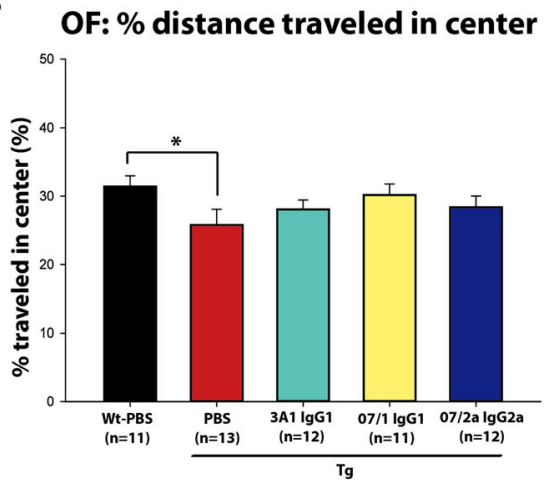

C

WTM: 07/2a IgG2a

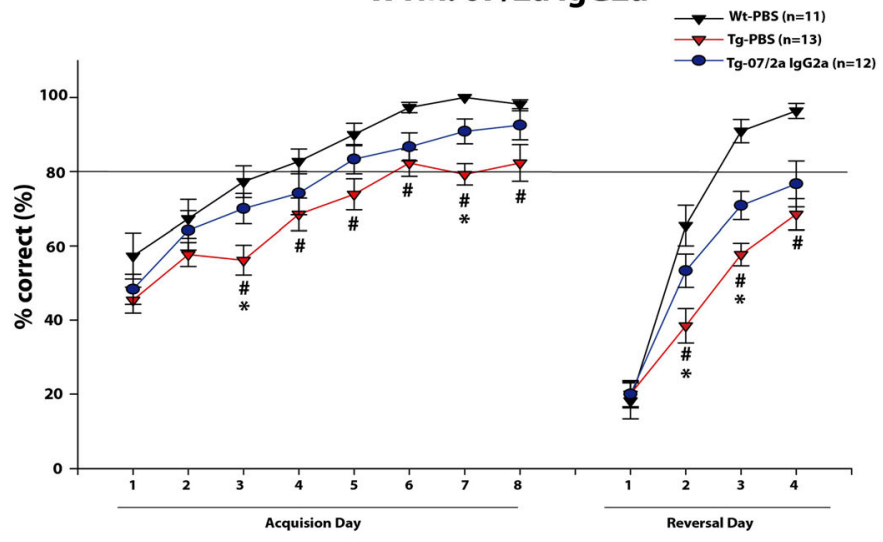

D

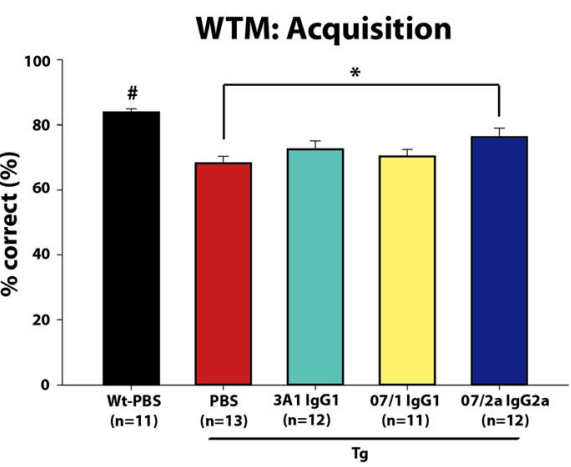

E

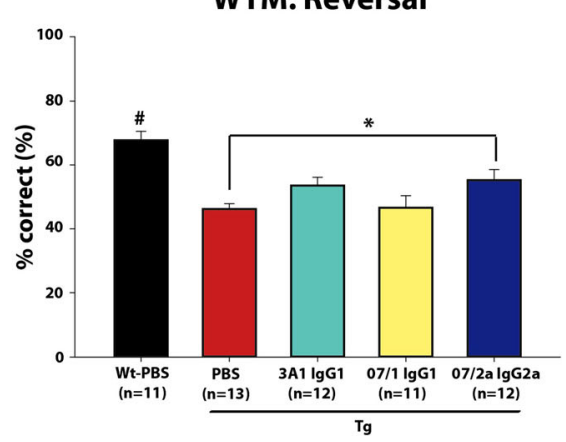

Fig. 1 Anti-pGlu-3 Aß IgG2a isotype mAb shows significant cognitive improvement in 15-mo-old Tg mice. No effect was observed on locomotor

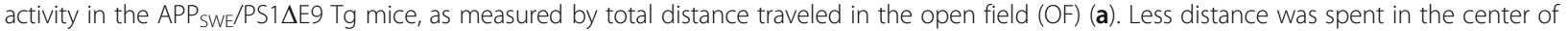
the OF by PBS-treated Tg versus Wt mice $(p<0.05)$, and $07 / 1$ treatment showed a trend $(p<0.0836)$ to reverse this $(\mathbf{b})$. Day by day analysis of the acquisition phase of the water T-maze (WTM) shows there were fewer $(p<0.05)$ correct responses to find the platform in PBS-treated Tg versus Wt mice on days 3-8 (c). 07/2-treated Tg mice displayed a significant increase $(p<0.05)$ in the percent of correct responses on days 3 and 7 compared to Tg PBS-treated mice (c). Day by day analysis of the reversal phase of the WTM (c) demonstrated a reduction $(p<0.05)$ in percent of correct responses on days $2-4$ by the PBS-injected Tg vs. Wt mice, indicating that the Tg mice had impaired cognitive flexibility. A significant increase in correct responses was observed in Tg mice treated with 07/2a $(p<0.05)$ on days 2 and 3 (c). WTM results averaged across all days confirmed that Tg mice made significantly fewer $(p<0.05)$ correct responses to find the platform compared to Wt PBS-injected mice in both the acquisition and reversal phases, which appeared to be partially rescued following 07/2a $(p<0.05)$ treatment compared to PBS Tg mice $(\mathbf{d}$, e). $n=$ 11-13 per group. All data are expressed as the mean \pm SEM. Fisher's PLSD: a ${ }^{*} p<0.05$ Wt PBS versus Tg 3A1, $\operatorname{Tg} 07 / 1$, and Tg 07/2a at 10 and 20 min, $p<0.05$ Wt PBS versus Tg 07/1, Tg 07/2a at 30 min, ${ }^{\#} p<0.05$ Wt PBS versus Tg PBS. $\mathbf{b}, \mathbf{d}$, and $\mathbf{e}^{*} p<0.05$ versus Tg PBS, ${ }^{*} p<0.05$ Wt PBS versus all groups. $\mathbf{C}^{*} p<0.05 \mathrm{Tg}$ PBS versus 07/2a, ${ }^{*} p<0.05 \mathrm{Wt}$ PBS versus Tg PBS 


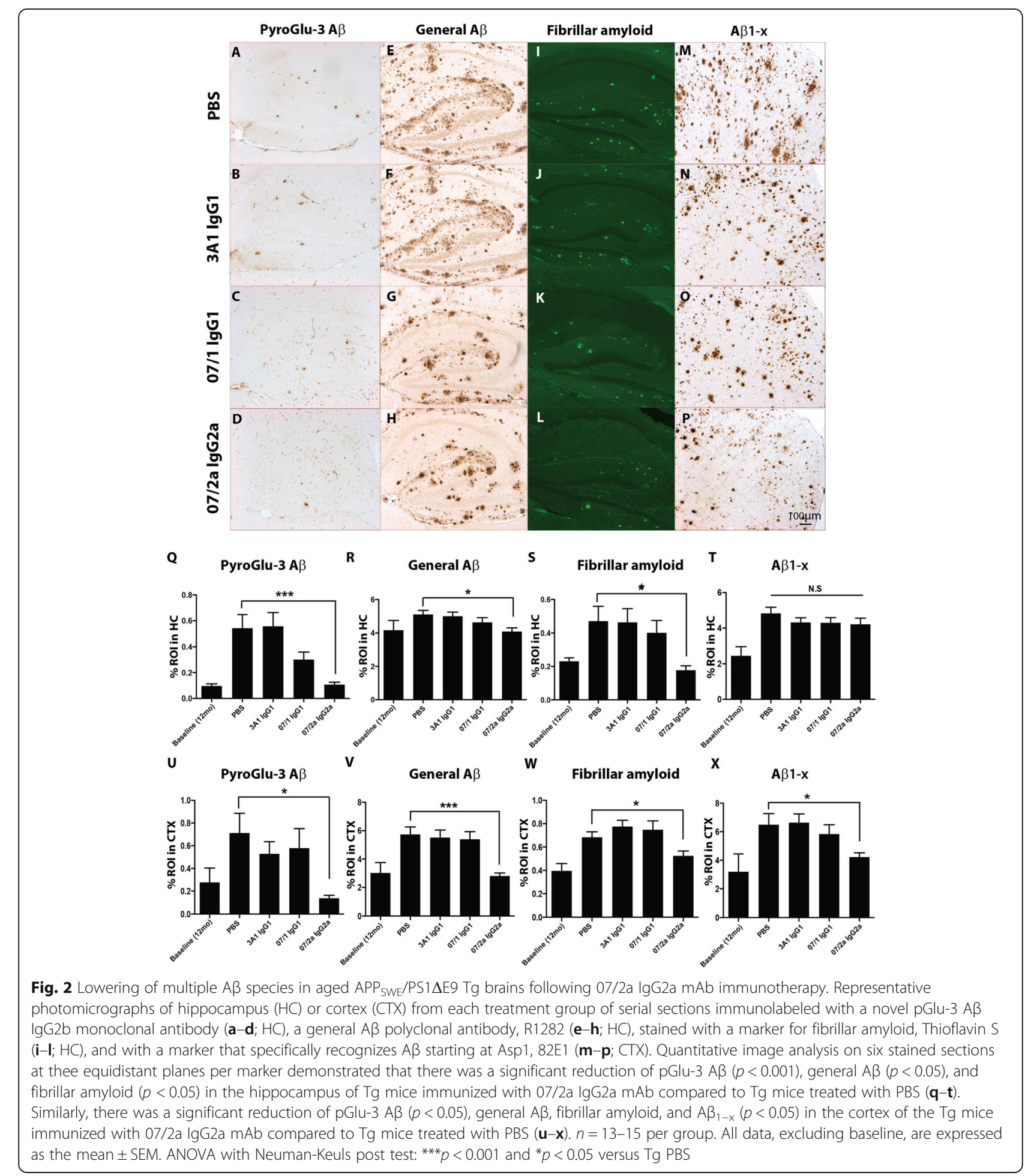

investigators blinded to the treatment of each mouse. No significant differences were observed between antibody treatment groups and PBS controls (Fig. 3h) indicating that none of the antibodies increased the incidence of microhemorrhage. 07/2a treatment reduced guanidine- $\mathrm{HCl}$-extracted $A \beta$ levels in brain homogenates

Biochemical analysis of guanidine- $\mathrm{HCl}$-extracted $\mathrm{A} \beta$ from whole brain (excluding cerebellum) homogenates demonstrated a significantly reduced concentration of 
A

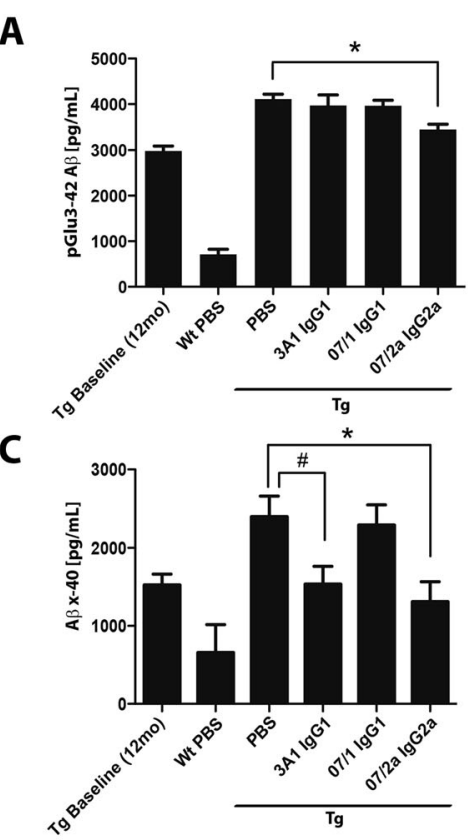

E

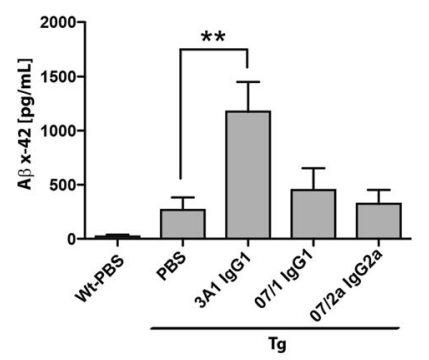

G

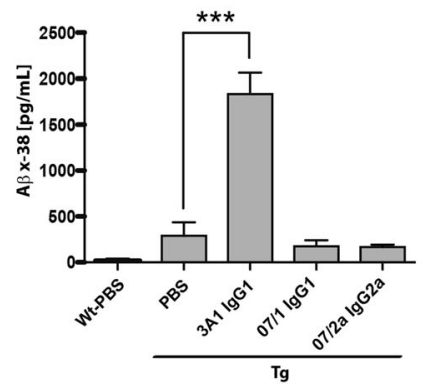

B

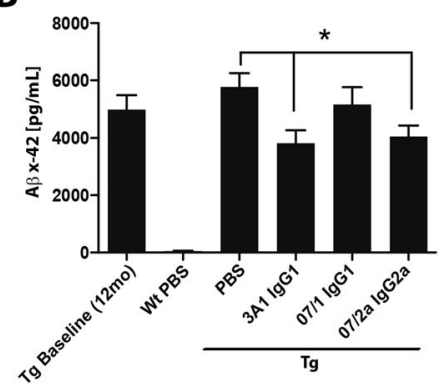

D

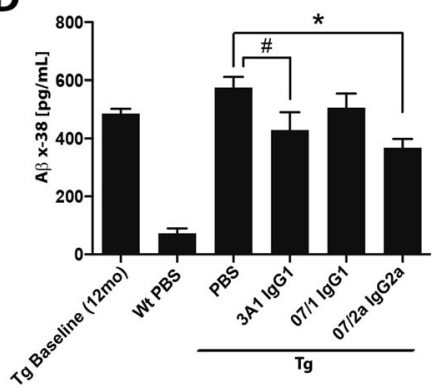

F

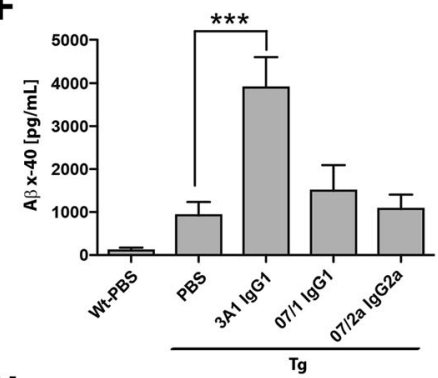

H

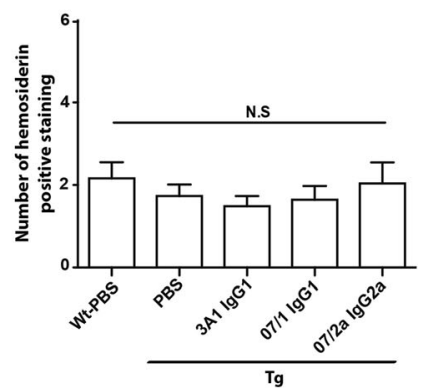

Fig. 3 07/2a lgG2a and 3A1 lgG1 mAb's lowered guanidine-HCl-extracted A 3 in aged APP ${ }_{S w E} / P S 1 \triangle E 9$ mice. Significant decreases in guanidineHCl-extracted pGlu-3 A $(p<0.05), A \beta x-42(p<0.01), A \beta x-40(p<0.05)$, and $A \beta x-38(p<0.05)$ were observed in Tg mice treated with 07/2a lgG2a mAb compared to PBS-treated Tg mice (a-d). Similarly, treatment with $3 \mathrm{~A} 1 \mathrm{mAb}$ reduced guanidine-HCl-extracted A $3 x-42(p<0.01)$, A $\beta x-40(p<$ 0.05 , $t$-test), and $A \beta x-38(p<0.05, t$-test) in Tg mice compared to PBS controls $(\mathbf{b}-\mathbf{d})$. Treatment of the Tg mice with $3 A 1 \lg G 1 \mathrm{mAb}$ resulted in a significant increase in plasma levels of $A \beta x-42(0.01), A \beta x-40(p<0.001)$, and $A \beta x-38(p<0.001)$ with no differences observed in Tg mice treated with anti-pGlu-3 A 3 mAbs, 07/1 lgG1 or 07/2a IgG2a, compared to PBS-treated Tg mice (e- $\mathbf{g}$ ). No significant (N.S) differences in hemosiderinpositive staining were observed between antibody-treated Tg mice versus PBS-injected Tg mice or WT mice (h). $n=13-15$ per group. All data, excluding baseline, are expressed as the mean \pm SEM. ANOVA with Neuman-Keuls post test: ${ }^{* *} p<0.001,{ }^{* *} p<0.01$, and ${ }^{*} p<0.05$ versus Tg PBS. Student's t-test: ${ }^{\#} p<0.05$

pGlu-3A $\beta$ in the insoluble fraction from $07 / 2 a-t r e a t e d$ Tg mice compared to Tg PBS control mice $(p<0.05)$ (Fig. 3a). The levels of insoluble $A \beta x-42$ were significantly lower in the $07 / 2 \mathrm{a}-$ and 3A1-treated mice compared with Tg PBS-injected mice $(p<0.05)$ (Fig. 3b). In addition, 07/2a-treated mice had significantly lower $\mathrm{A} \beta \mathrm{X}-40(p<0.05)$ and $\mathrm{A} \beta \mathrm{x}-38(p<0.05)$ in the insoluble $A \beta$ fraction relative to Tg PBS control mice (Fig. 3c, d). 
A trend for reduction in $A \beta x-40$ and $A \beta x-42$ was observed by 3A1-treated mice compared to PBS-injected Tg mice and was significant when compared to PBS controls by Student's $t$ test $(p<0.05)$ (Fig. 3c, d). There were no significant changes in soluble $A \beta x-40$ and $A \beta x-$ 42 levels in the T-PER extracted $A \beta$ homogenates (data not shown) and the pGlu- $3 \mathrm{~A} \beta$ and $A \beta \mathrm{x}-38$ levels in this fraction were below the detection limit for their respective $A \beta$ ELISAs.

\section{$07 / 2 a$ treatment did not alter plasma $A \beta$ levels}

Reduction of $A \beta$ burden by altering the equilibrium between CNS and plasma $A \beta$, otherwise known as the "peripheral sink" hypothesis, has been demonstrated in previous immunotherapy studies as a mechanism of plaque reduction in the brain $[4,36]$. To investigate if there were changes in peripheral $A \beta$ levels in the antibody-treated Tg mice, terminal plasma was collected from all mice and $A \beta$ was measured by an MSD immunoassay. Tg mice treated with $3 \mathrm{~A} 1$ showed dramatic increases in $\mathrm{A} \beta \mathrm{x}-42(p<0.01), \mathrm{A} \beta \mathrm{x}-40 \quad(p<0.001)$, and $\mathrm{A} \beta \mathrm{x}-38(p<0.001)$ levels compared with Tg PBS control mice (Fig. 3e-g). Interestingly, the pGlu-3 A $\beta$ mAbs, 07/ 1 and 07/2a, showed no significant changes in $A \beta$ levels compared to Tg PBS control mice suggesting less antibody binding in the periphery and, perhaps, an alternative mechanism of plaque removal. Similar to our prevention study [12], we did not see detectable levels of pGlu-3 $\mathrm{A} \beta$ in the plasma in these $\mathrm{APP}_{\mathrm{SWE}} / \mathrm{PS} 1 \Delta \mathrm{E} 9 \mathrm{Tg}$ mice (data not shown). We also examined cytokine and chemokine levels in the plasma of the mice in this study to determine if the treatments had any pro- or antiinflammatory effects; however, after measuring for changes in IFN $\gamma$, IL-2, IL-4, IL-5, IL-6, IL-10, IL-12p70, KC-GRO, and TNF $\alpha$ levels by MSD immunoplatform (Additional file 1: Figure S1), only KC-GRO (also known as CXCL1 chemokine) levels demonstrated a difference with $07 / 2$ a-treated mice showing a significant reduction $(p<0.05)$ compared to PBS-injected transgenic mice (Additional file 1: Figure S1H).

\section{Exogenous antibody concentrations were elevated in the} CNS and periphery according to the immunizing antibody The amount of 07/1,07/2a, and 3A1 exogenous antibodies present at sacrifice in the CNS and plasma were measured by ELISA in the T-PER soluble brain homogenates (Additional file 1: Figure S2A-C) and plasma (Additional file 1: Figure S2D-F). We observed an increase in plasma pGlu-3 A $\beta$ antibody levels in 07/1 ( $52,000 \mathrm{ng} / \mathrm{mL})$ and $07 / 2 \mathrm{a}$-treated mice $(\sim 58,000 \mathrm{ng} / \mathrm{mL})$ (Additional file 1: Figure S2E-F). No antibodies recognizing pGlu3-12 $\mathrm{A} \beta$ were detected in plasma from $3 \mathrm{~A} 1$ or PBS-injected mice, supporting 07/1 and 3A1 mAb's specificities (Additional file 1: Figure S2E-F). In contrast, circulating antibodies that recognized $A \beta 1-18$ were present in 3A1-immunized mouse plasma $(\sim 82,000 \mathrm{ng} /$ $\mathrm{mL}$ ) (Additional file 1: Figure S2D) but not in either of the pGlu-3 A $\beta$ immunization groups or PBS-injected $\mathrm{Tg}$ controls (Additional file 1: Figure S2D). In parallel, increases in exogenous antibody levels, albeit at lower concentrations, were observed in the T-PER soluble brain fractions from saline-perfused mice. This demonstrates that a fraction of the exogenous antibodies administered in the periphery were able to penetrate the CNS. In the brain, $\sim 250,000 \mathrm{pg} / \mathrm{mL}$ antibodies that recognized pGlu3-12 A $\beta$ from 07/1 immunized $\mathrm{Tg}$ mice and $\sim 425,000 \mathrm{pg} / \mathrm{mL}$ antibodies from $07 / 2 \mathrm{a}$ immunized mice were detected (Additional file 1: Figure S2B-C). No pGlu3-A $\beta$-specific antibodies were detected in soluble brain homogenates from 3A1immunized or PBS-injected mice (Additional file 1: Figure S2B-C). Although lower than the amount of A 1-18-recognizing antibodies that were detected in the plasma, soluble brain homogenates from 3A1immunized mice had concentrations of $40,000 \mathrm{pg} / \mathrm{mL}$ antibodies (Additional file 1: Figure S2A). There was a very small amount of A $\beta 1-18$-recognizing antibodies in brain in the $07 / 1$-treated mice but no appreciable amounts from 07/2a- or PBS-injected Tg mice detected (Additional file 1: Figure S2A). We also carried out immunohistochemical analysis on brain sections with biotinylated anti-mouse IgG1 and anti-mouse IgG2a secondary antibodies alone to detect the immunizing antibodies in brain. Adjacent sections were stained with R1282 and pGlu-3 A $\beta$ 07/2b antibodies to identify plaques. Biotinylated IgG1 secondary antibody detected a subset of cerebral plaques in 3A1treated and 07/1-treated mice while biotinylated IgG2a secondary antibody recognized a subset of plaques in 07/2a-treated mice (Additional file 1: Figure S3).

\section{7/2a treatment increased plaque-associated microgliosis} in the hippocampus and cortex

To evaluate if there were changes in glial accumulation in $\mathrm{HC}$ and CTX of these mice, IR with a marker for microglia and macrophage, Iba1, was quantified on three sections at equidistant planes. A significant increase in Iba1-positive staining was observed in the mice treated with $07 / 2$ a compared to PBS-injected Tg mice in both the $\mathrm{HC}(p<0.05)$ and the CTX $(p<0.05)$ but not observed in the groups treated with $07 / 1$ and $3 \mathrm{~A} 1$ (Fig. $4 \mathrm{a}-$ e, $\mathrm{k}, \mathrm{l}$ ). We also measured IR in these treatment groups with a microglial and macrophage marker of phagocytosis, CD68. We observed from analysis of this phagocytic marker that $07 / 2$ a was the only mAb treatment to demonstrate a significant increase compared to PBS control $\mathrm{Tg}$ mice in the $\mathrm{HC}$ (Fig. $4 \mathrm{~m} ; p<0.01$ ) and CTX 


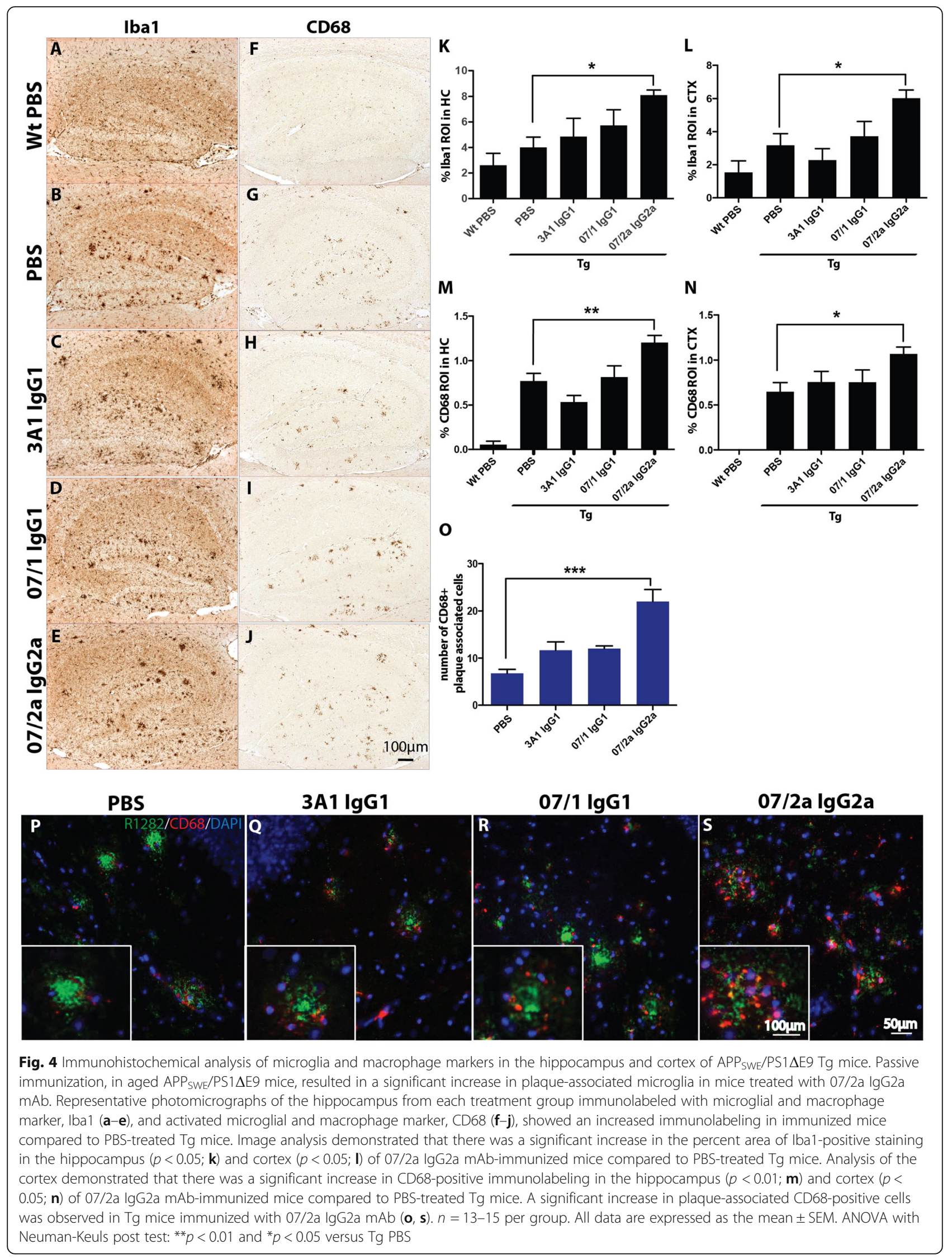


(Fig. 4n; $p<0.05$ ). We carried out double immunofluorescence (IF) staining on the tissue with a general $A \beta$ marker, R1282, and CD68 and measured, specifically in the hippocampus, the number of CD68-positive cells surrounding plaques. We found that $07 / 2 \mathrm{a}$-treated $\mathrm{Tg}$ mice had a significant amount of CD68-positive, plaqueassociated cells as semi-quantitatively measured compared to the PBS control mice (Fig. 4o, s).

\section{The IgG subclass of anti-pGlu3-antibodies affected $A \beta$ phagocytosis ex vivo}

In order to address the mechanism of plaque removal by $07 / 1,07 / 2 \mathrm{a}$, and $07 / 2 \mathrm{a}-\mathrm{k}$ by potentially mediating microglial phagocytosis of $A \beta$, we assessed plaque clearance by microglia from unfixed, frozen brain tissue of aged $\mathrm{APP}_{\mathrm{SWE}} / \mathrm{PS} 1 \Delta \mathrm{E} 9 \mathrm{Tg}$ mice in an ex vivo phagocytosis assay. Previous studies have demonstrated that $\mathrm{A} \beta$ antibody added to tissue sections, binds to plaques, and initiates plaque clearance through Fc-receptor-mediated phagocytosis $[4,5]$. Prior to initiation of the assay, we first determined whether the pGlu-3-42 A $\beta$ epitope was accessible in the unfixed frozen tissue from a 20-mo-old $\mathrm{APP}_{\mathrm{SWE}} / \mathrm{PS} 1 \Delta \mathrm{E} 9$ mouse. Robust immunofluorescence detection with $07 / 1 \mathrm{mAb}$ was observed in the cortex and hippocampus, with staining to a lesser extent observed in the cerebellum (Additional file 1: Figure S4A-C), suggesting sufficient pGlu-3-42 antigen was present to allow for Fc-receptor-mediated phagocytosis. Ex vivo phagocytosis assays were conducted, and $\mathrm{A} \beta$ plaque load/levels were measured by either immunofluorescent staining or ELISA, and the results were expressed as a ratio of the relevant isotype control. There were no significant differences in R1282 IR (data not shown) between tissue that had $24 \mathrm{~h}$ incubation with media alone (no cells) (Fig. 5a) and incubation with PMG (Fig. 5b), suggesting that without the addition of an $\mathrm{A} \beta$ antibody, phagocytosis is negligible. Similar R1282 IR levels were also seen in the tissue pre-incubated with IgG isotype control antibodies and PMG compared with PMG alone, eliminating nonspecific Fc-receptor binding initiating clearance (Fig. 5d, g). Following $24 \mathrm{~h}$ incubation of the tissue with PMG, there was a significant reduction in R1282-positive staining present in the tissue pre-incubated with $07 / 2 \mathrm{a}$ mAb compared to incubation with IgG2a isotype control $(p<$ 0.001 ) whereas exposure with the pGlu-3 A $\beta$ IgG1 and $07 / 2 \mathrm{a}-\mathrm{k}$ mAbs did not promote a significant reduction (Fig. 5a-h). Analysis of the guanidine- $\mathrm{HCl}$ insoluble $\mathrm{A} \beta$ homogenates by ELISA demonstrated that there was a significant decrease in pGlu-3 A $\beta$ following incubation with the tissue with both $07 / 1(p<0.05)$ and $07 / 2 \mathrm{a}(p<$ $0.05)$ (Fig. 5i). A $\beta x-40$ levels were only reduced with exogenous addition of the IgG2a antibodies, 07/2a $(p<$ $0.05)$ and $07 / 2 \mathrm{a}-\mathrm{k}(p<0.01)$ (Fig. 5j), whereas there were no significant differences in $\mathrm{A} \beta \mathrm{x}-42$ levels observed following incubation of any of the $A \beta$ mAbs in the ex vivo phagocytosis assay (Fig. 5k). These results were mostly confirmed in another set of ex vivo phagocytosis assays using N9 cells, a murine immortalized microglial cell line (Additional file 1: Figure S5).

An accompanying in vitro assessment of the $\mathrm{Fc} \gamma$ receptor binding of $07 / 2 \mathrm{a}$ and $07 / 2 \mathrm{a}-\mathrm{k}$ to isolated CD16, CD32, and CD64, i.e., the Fc $\gamma$ receptor components, revealed no profound differences of the two antibodies (Table 1). In addition, binding affinities to pGlu-3 A $\beta$ were similar between 07/1 (10.2 nM), 07/2a (9.8 nM), and $07 / 2 \mathrm{a}-\mathrm{k}(8.08 \mathrm{nM})$.

\section{$07 / 2 \mathrm{a}$ and $07 / 2 \mathrm{a}-\mathrm{k}$ treatment of $\mathrm{hAPP} \mathrm{SL}_{\mathrm{SL}} \mathrm{hQC}$ mice reduced $A \beta$}

We next compared two doses of the 07/2a antibody (150 and $500 \mu \mathrm{g})$ and one dose of $07 / 2 \mathrm{a}-\mathrm{k}(500 \mu \mathrm{g})$ for their ability to clear $\mathrm{A} \beta$ in a plaque-rich $\mathrm{AD}$ model. Overall, $\mathrm{A} \beta$ clearance was similar between $07 / 2 \mathrm{a}-\mathrm{k}$, compared to that seen with $07 / 2 \mathrm{a}$ (Fig. 6). pGlu-3 A $\beta(p<0.05)$ and general $\mathrm{A} \beta(p<0.01)$ immunoreactivity in the hippocampus showed significant reductions by $07 / 2 \mathrm{a}-\mathrm{k}$, similar to that of $07 / 2$ a-treated mice (Fig. 6a, b). The plaquelowering potential of the CDC mutant antibody was further confirmed in the TBS soluble fraction isolated from the hemibrain of the treated mice and potentially containing toxic oligomers (Fig. 6c), although insoluble $A \beta$ levels were not significantly altered. 07/2a IgG2a immunotherapy in these mice demonstrated a dosedependent effect in $A \beta$ reduction (Fig. 6a-c).

\section{Longitudinal PET imaging demonstrated treatment with pGlu-3 $A \beta$ mAbs of different lgG isotypes resulted in distinct glial activation characteristics}

Different Ig isotypes of antibody used in passive immunization studies can have various influences on microglial activation, which may result in different mechanisms of $\mathrm{A} \beta$ clearance. Thus, it is important to compare different Ig isotypes against the same target for their effect on clearing $A \beta$ and inducing transient and/or chronic neuroinflammation. We performed microPET imaging using a second-generation TSPO (translocator protein, a marker for activated microglia) PET tracer, ${ }^{18} \mathrm{~F}-\mathrm{GE} 180$, to visualize the differences in microglial activation prior (baseline, day 0 ) to and following i.p. passive immunization (days 3 and 30) with 3 anti-pyroGlu3 $A \beta$ mAbs (07/1 IgG1, 07/2a IgG2a, and 07/2a-k, a CDC mutant version of $07 / 2 \mathrm{a}$ IgG2a to avoid complement activation), a general $\mathrm{A} \beta$ IgG1 mAb (3A1), or PBS in young (pre-plaque, 4-mo-old) or aged (plaque-rich, 14-16-moold) male $\mathrm{APP}_{\mathrm{SWE}} / \mathrm{PS} 1 \Delta \mathrm{E} 9 \mathrm{Tg}$ mice.

The time-activity curve (TAC) of ${ }^{18}$ F-GE180 uptake in the hippocampus was analyzed using CT/PET/MRI coregistration. There were no differences in hippocampal 


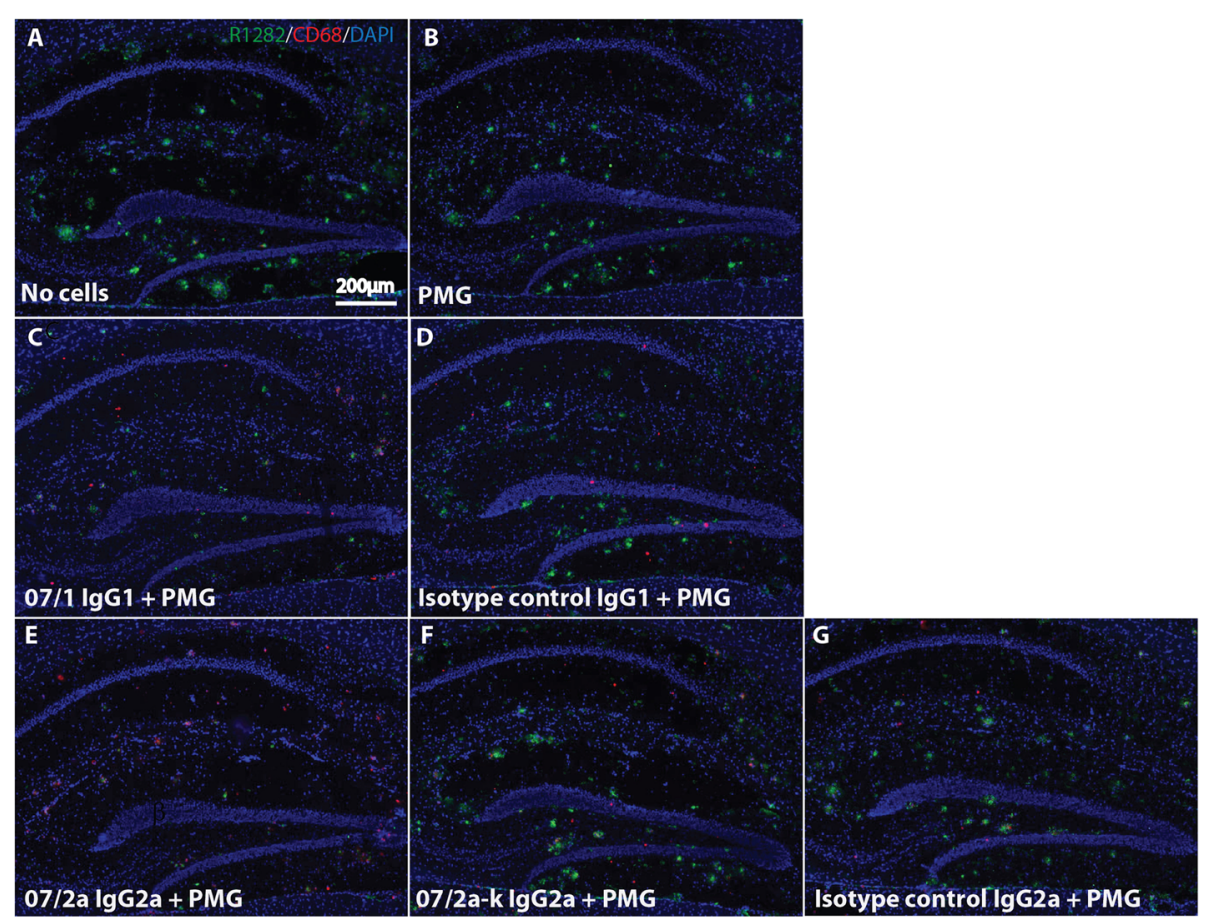

H
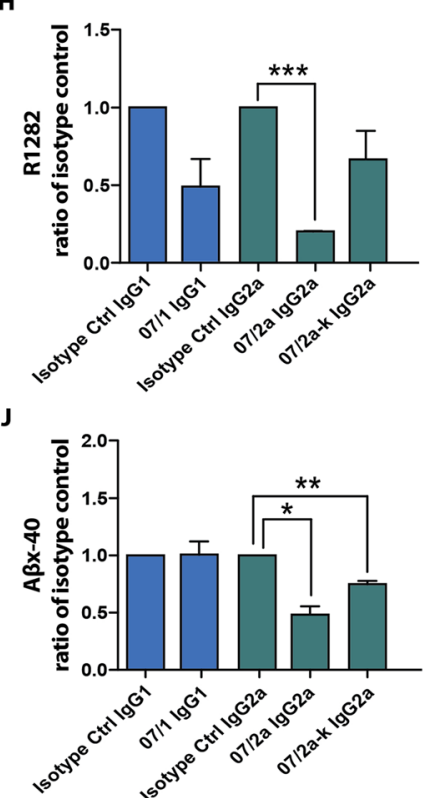

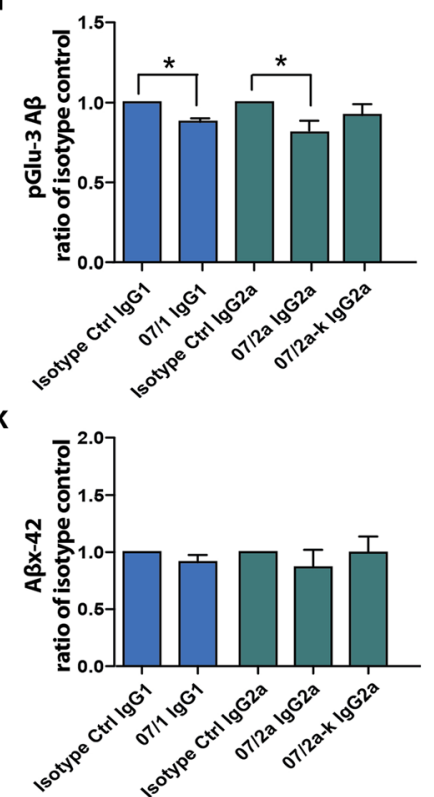

Fig. 5 Ex vivo antibody-mediated phagocytosis assay demonstrates differences in plaque clearance based on antibody isotype. Unfixed, frozen plaque-rich tissue sections $(20 \mu \mathrm{m})$ from 20-mo-old APP SWE $/$ PS1 $\triangle$ E9 Tg mice were pre-incubated with the following antibodies for $1 \mathrm{~h}: 07 / 1 \mathrm{lgG}$, isotype control lgG1, 07/2a lgG2a, 07/2a-k lgG2a, or isotype control lgG2a. Following washing, the tissue was incubated with primary murine microglia (PMG) for $24 \mathrm{~h}$ and $A \beta$ levels were determined. Representative photomicrographs of the hippocampus from each treatment group coimmunolabeled with a general Aß marker, R1282, an activated microglial and macrophage marker, CD68 and a nucleic acid dye, DAPI (a-g) and showed decreased R1282 immunolabeling in the hippocampus of tissue pre-incubated with 07/2a lgG2a compared to isotype control (a-h). pGlu-3 $A \beta, A \beta x-40$, and $A \beta x-42$ levels were also determined by ELISA (i-k). Significant reductions in pGlu-3 A $\beta$ were observed in tissue preincubated with $07 / 1 \mathrm{lgG} 1$ and $07 / 2 \mathrm{lgG} 2 \mathrm{mAbs}$ compared to their respective isotype controls (i). Tissue incubation with 07/2a lgG2a and 07/2a-k IgG2a resulted in decreased $A \beta x-40$ levels compared to isotype control (j). There were no differences in $A \beta x-42$ levels observed between groups (k). $n=3$ per group. All data are expressed as the mean \pm SEM. ANOVA with Neuman-Keuls post test: ${ }^{* * *} p<0.001,{ }^{* *} p<0.01$, and ${ }^{*} p<0.05$ versus isotype control 
Table $1 K_{D}$ values of antibody binding to Fcy receptor subtypes based on ELISA using immobilized receptor

\begin{tabular}{lll}
\hline Fcy receptor $K_{D}(\mu \mathrm{g} / \mathrm{ml})$ & & \\
\hline Receptor & $07 / 2 \mathrm{algG2a}$ & $07 / 2 \mathrm{a}-\mathrm{k} \operatorname{lgG} 2 \mathrm{a}-\mathrm{k}$ \\
\hline CD16A & 0.39 & 0.67 \\
CD32 & 0.68 & 1.50 \\
CD64 & 0.21 & 0.39 \\
\hline
\end{tabular}

TAC of ${ }^{18} \mathrm{~F}$-GE180 at day 0 (baseline), 3, or 30 in 4-moold and 16-mo-old $\mathrm{APP}_{\mathrm{SWE}} / \mathrm{PS} 1 \triangle \mathrm{E} 9$ mice with PBS injection (Fig. 7a, f). Following a single injection of $07 / 1$ $\mathrm{mAb}$, a significant increase in hippocampal ${ }^{18} \mathrm{~F}-\mathrm{GE} 180$ uptake was found at day 30 versus baseline in 4-mo-old $\left(F_{(1,8)}=5.62 ; p<0.05\right)$ (Fig. $\left.7 \mathrm{c}\right)$ and 16 -mo-old $\left(F_{(1,8)}=\right.$ 10.54; $p<0.05)$ mice (Fig. 7h). Four-month-old APP/ PS1dE9 mice injected with 07/2a antibody showed overt elevation in ${ }^{18} \mathrm{~F}$-GE180 uptake at day $3\left(F_{(1,8)}=3.52\right.$; $p=$ 0.097 , trend $)$ and day $30\left(F_{(1,8)}=5.62 ; p<0.05\right)$ compared to baseline (Fig. 7d), while 16-mo-old APP/PS1dE9 mice treated with the same antibody showed a significant increase in hippocampal ${ }^{18} \mathrm{~F}$-GE180 uptake at day 3 $\left(F_{(1,8)}=7.28 ; p<0.05\right)$ but a decrease at day $30\left(F_{(1,8)}=\right.$ $15.84 ; p<0.01$ ) (Fig. 7i). No significant changes in hippocampal ${ }^{18}$ F-GE180 uptake were observed at day 3 or day 30 at either age in mice treated with $07 / 2 \mathrm{a}-\mathrm{k} \mathrm{mAb}$ (Fig. 7e, j). Although the 3A1-injected 4-mo-old APP/ PS1dE9 mice showed a consistent reduction of ${ }^{18} \mathrm{~F}$ GE180 hippocampal uptake at day $3\left(F_{(1,8)}=18.0 ; p<\right.$ $0.01)$ and 30 versus baseline $\left(F_{(1,8)}=3.77 ; p=0.088\right.$, trend), these mice had abnormally high baseline tracer uptake (Fig. 7b). Similar results were observed in the whole brain TAC of ${ }^{18} \mathrm{~F}$-GE180 uptake (Additional file 1: Figure S6).

\section{Discussion}

The presence of pGlu-3 A $\beta$ in human brains exclusively under pathological conditions, in addition to its increased stability and propensity to aggregate, makes this peptide an attractive therapeutic target $[14,18,20]$. Compelling evidence now suggests that the N-terminal modification induces formation of toxic structures such as oligomers and membrane pores [17, 19, 22, 37, 38]. Therefore, anti-pGlu-3 A $\beta$ treatment strategies by inhibition of glutaminyl cyclase or immunotherapy are currently in development $[32,39]$. The targeting of pGlu-3 $A \beta$ by passive immunotherapy differs from other $A \beta$ antibody treatments in various aspects: (i) pGlu-3 $A \beta$ is a highly pathologic and neurotoxic species, (ii) the targeting of the $\mathrm{N}$-terminal $\mathrm{A} \beta$ modification efficiently rules out binding to parent molecules (e.g., APP and non-modified beta CTF), preventing potential side effects, and (iii) pGlu-3 A $\beta$ is undetectable in plasma; thus, there is no "peripheral capture" of the drug expected in the circulation [12].

Accordingly, our nonclinical prevention studies have demonstrated a lowering of plaque burden when targeting pGlu-3 $A \beta$ early in young Tg mice by immunotherapy $[12,32,40]$. The aim of this study was to investigate the effect of passive immunization of murine anti-pGlu$3 \mathrm{~A} \beta \mathrm{mAbs}$ of different IgG isotypes, in a therapeutic paradigm, on cognition and plaque burden in aged, plaque-rich $\mathrm{APP}_{\mathrm{SWE}} / \mathrm{PS} 1 \triangle \mathrm{E} 9 \mathrm{Tg}$ mice and, thus, to provide avenues for the humanization of the drug molecule. A pilot study previously conducted by our lab demonstrated an attenuation of $A \beta$ plaque deposition in aged $\mathrm{APP}_{\mathrm{SWE}} / \mathrm{PS} 1 \triangle \mathrm{E} 9 \mathrm{Tg}$ mice following peripheral administration of $07 / 1 \mathrm{mAb}$ after the onset of cerebral $A \beta$ deposition [24]; however, this small study did not examine the effects of administration of an IgG2a-specific pGlu-3 $\mathrm{A} \beta \mathrm{mAb}$ nor the effects of both antibody isotypes on cognition. Therefore, these were amongst the main objectives of the present study.

In our present therapeutic study, pathological examination of chronic treatment effects of anti-pGlu3 A $\beta$ IgG1 and IgG2a mAbs demonstrated reduced brain amyloid plaque burden and brain pGlu-3 $A \beta, A \beta x-42, A \beta x-40$, and $A \beta x-38$ peptide levels. These results, in part, corroborated findings published by Eli Lilly [32], describing a reduction in guanidine- $\mathrm{HCl}$ extracted $\mathrm{A} \beta 1-42$ in the hippocampus and cortex of PDAPP mice treated for 3 months with an anti-pGlu-3 A $\beta$ antibody, mE8 IgG2a. However, the Lilly study did not show any differences measured by histopathological analysis. In our current study, 07/2a treatment not only demonstrated a decrease of cerebral pGlu-3 A $\beta$ plaque deposition but also other forms of $A \beta$ in the brain suggesting that by reducing pGlu-3 $A \beta$, it removed the seeds for further plaque deposition, a mechanism by which pGlu-3 $\mathrm{A} \beta$ has been reported to trigger AD pathogenesis [19]. Interestingly, we observed a significant increase in the amount of positive microglial/macrophage staining in the hippocampus and cortex of the 07/2a-treated mice compared to control PBS mice, suggesting that the $A \beta$ reduction observed in this immunotherapy study may be a result of a microglial-mediated mechanism of removal of amyloid deposits in the $\mathrm{Tg}$ mouse brain. Early studies have shown that microglia not only accumulate around $A \beta$ plaques in $\mathrm{AD}$, but are also able to contribute to their clearance [41, 42]. Mutations on microglial receptors that play a role in phagocytosis have been associated with an increased risk of developing AD [43-46] making this mechanism, or lack thereof, a strong contending explanation for the accumulation of $A \beta$ observed in $A D$. IgG antibodies can act as opsonins, which in the context of this study, bind to general $A \beta$ or pGlu-3 $A \beta$, to tag them for phagocytosis through recognition of the $\mathrm{Fc}$ 
A

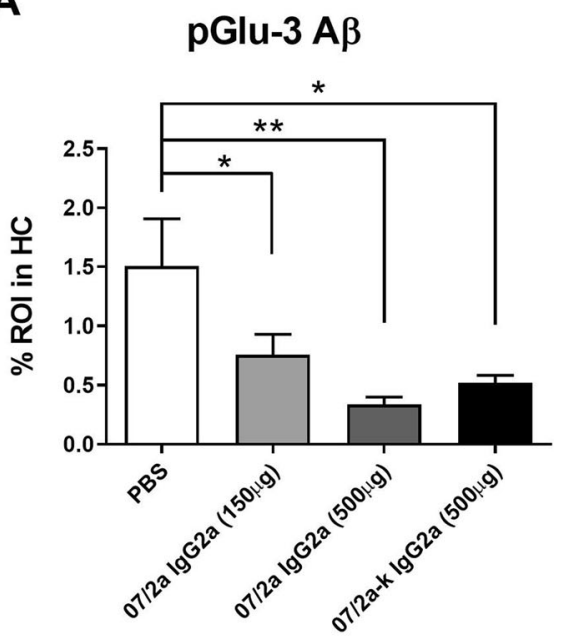

B

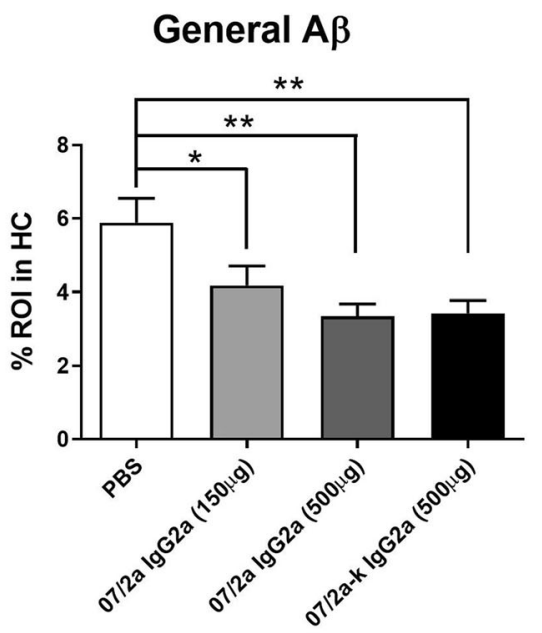

C

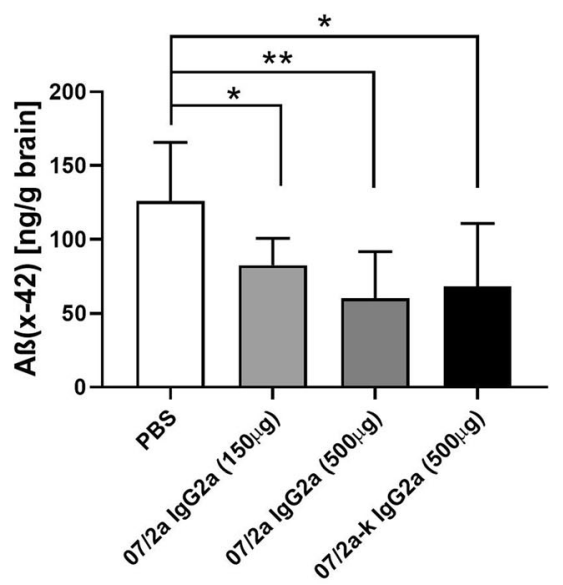

Fig. 6 07/2a and 07/2a-k immunotherapy lowers AB in hAPP ${ }_{S L}: h Q C$ mice. Quantitative image analysis of the hippocampus on six stained sections at three equidistant planes per marker demonstrated that there was a significant reduction of $\mathrm{pGlu}-3 \mathrm{~A} \beta$ following 4 months of treatment with 07/2a at $150 \mu \mathrm{g}(p<0.05), 07 / 2 \mathrm{a}$ at $500 \mu \mathrm{g}(p<0.01)$, and $07 / 2 a-k$ at $500 \mu \mathrm{g}(p<0.05)(\mathbf{a})$. General $A \beta$ as measured by R1282 IHC demonstrated a reduction after dosing with 07/2a at $150 \mu \mathrm{g}(p<0.05), 07 / 2 \mathrm{a}$ at $500 \mu \mathrm{g}(p<0.01)$, and 07/2a-k at $500 \mu \mathrm{g}$ $(p<0.01)(\mathbf{b}) . A \beta_{x-42}$ levels measured in the TBS soluble fraction were reduced in the brains of animals treated with $07 / 2 \mathrm{a}$ at $150 \mu \mathrm{g}(p<$ $0.05), 07 / 2 \mathrm{a}$ at $500 \mu \mathrm{g}(p<0.01)$, and 07/2a-k at $500 \mu \mathrm{g}(p<0.05)(\mathbf{c})$. $n=7-8$ mice per group. All data are expressed as the mean \pm SEM. ANOVA with Bartlett's post test: ${ }^{* * *} p<0.001,{ }^{* *} p<0.01$, and ${ }^{*} p<0.05$ versus isotype control

portion of the antibody by the Fc receptors on phagocytes $[5,47]$. We were able to measure a significant increase of CD68-positive staining, which is a marker for phagocytic microglia and macrophage, surrounding the plaques in the hippocampus of the anti- $\mathrm{A} \beta \mathrm{mAb}$-treated mice compared to the PBS-treated mice, with 07/2atreated mice showing the most robust plaque-lowering, further indicating this mechanism of clearance for this antibody.

Further confirmation of microglial activation by $07 / 2 \mathrm{a}$ IgG2a antibody was demonstrated by a significant increase in hippocampal and whole brain ${ }^{18} \mathrm{~F}$-GE180 uptake, a second-generation radioligand of TSPO (a marker for activated microglia), as measured by in vivo microPET imaging in the 4-mo- and 16-mo-old mice 3 days following a single injection of $07 / 2 \mathrm{a}$. Interestingly, microglial activation remained at high levels 30 days after $07 / 2$ a injection as compared to its baseline (day 0 ) in 4-mo-old mice that barely have pGlu-3 A $\beta$ pathologies; however, microglial activation was decreased at 30 days after $07 / 2 \mathrm{a}$ injection in 16-mo-old APP/PS1dE9 mice that were loaded with pGlu-3 A $\beta$ pathologies, implying that immunization of IgG2a isotype of an antipGlu-3 A $\beta$ mAb can effectively and rapidly evoke microglial reactivity in mouse brain within $72 \mathrm{~h}$, while chronic clearance of pGlu-3 A $\beta$ by even a single-dose injection of $07 / 2 \mathrm{a}$ can result in a reduction in brain inflammation.

Interestingly, the strong effect of $07 / 2 \mathrm{a}$ to elicit phagocytosis, $A \beta$ and pGlu-A $\beta$ clearance, and microglial activation also resulted in a cognitive improvement of the mice. We assessed learning and memory in the mice using the water T-maze behavioral paradigm. Although the treatment did not achieve a full rescue of spatial learning and memory, it clearly suggested that only the $07 / 2 \mathrm{a} \mathrm{mAb}$ provoked substantial cognitive benefits to these aged mice. In addition, 07/2a had the highest penetration into the brain followed by $07 / 1$, both of which were much higher than 3A1. Taken together, these results collectively suggest that a strong effector function of an anti-pGlu-3 antibody and good brain 


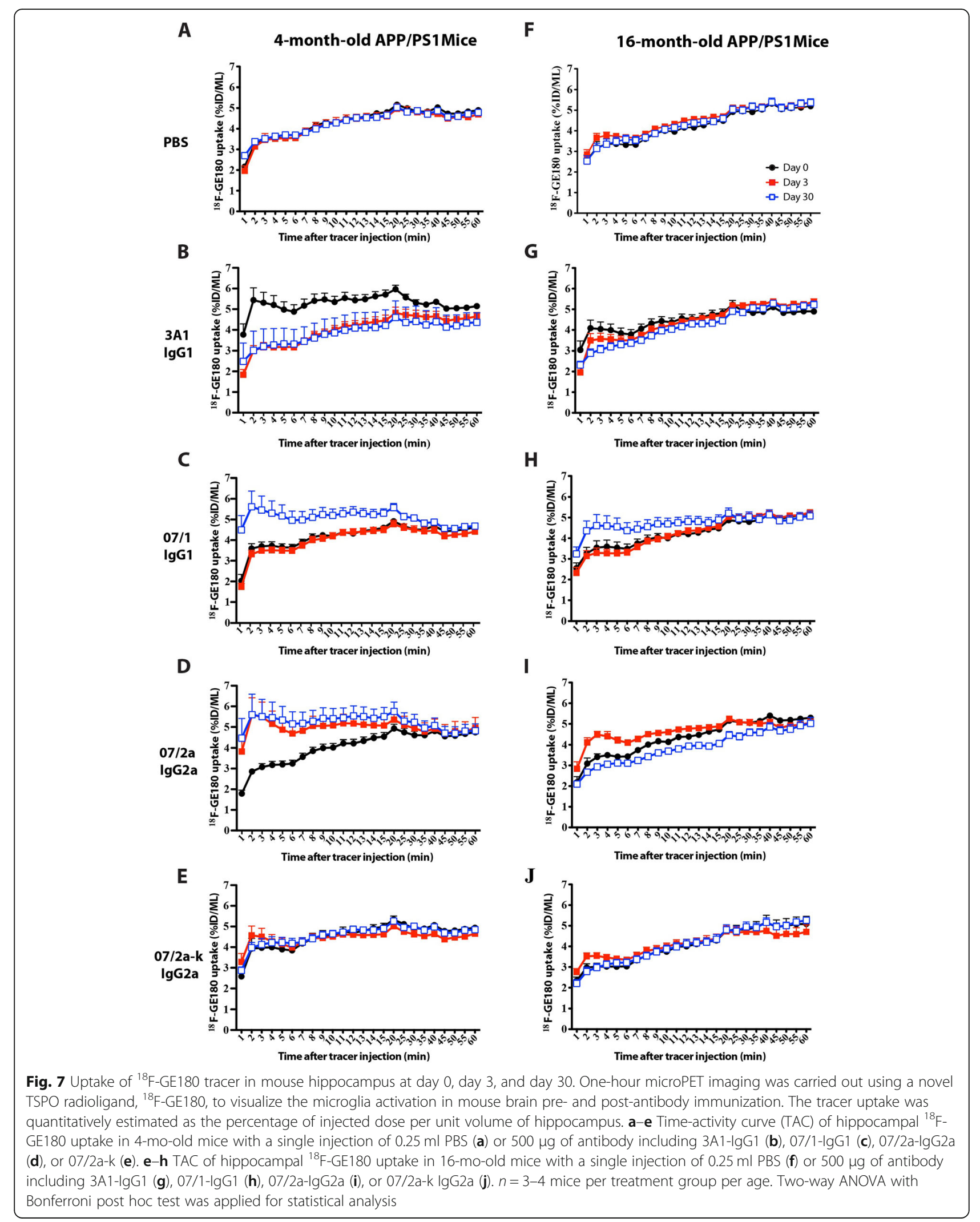


exposure are required to attenuate pathological changes and behavioral abnormalities in aged transgenic mice. Considering the effect on microglial activation and inflammation, it is important that we did not observe an incidence of microhemorrhages. Immunotherapy in aged APP transgenic mice can pose the risk of creating microbleeds [33, 35], which has been a fairly accurate predictor of what has occurred in the clinics with some treatments [48, 49]. Although our mice were 12 months of age at the start of immunization and 16 months at study completion, it may be possible that the incidence of microbleeds would be higher in even older APP/PS1 mice, as demonstrated by $\mathrm{Li}$ et al. when comparing microhemorrhage in middle-aged APP/PSI mice and old APP mice following a 3-month immunotherapy regimen [50].

Although none of the treatments showed an increased risk of microbleeds, we observed differences between the antibodies in the potential to reduce $A \beta$ burden in the brain and increase plasma $A \beta$ levels. A number of mechanisms for $A \beta$ clearance have been suggested such as the breakdown of amyloid deposits [51, 52], removal of cerebral $A \beta$ through "pulling" $A \beta$ from brain to plasma, termed "peripheral sink" $[4,36]$, and $A \beta$ plaque removal through microglial-mediated phagocytosis [53, 54]. In our study, the increased levels of $\mathrm{A} \beta$ species measured in the plasma of saline-perfused $\mathrm{Tg}$ mice treated with our positive control, 3A1, compared with the Tg PBSinjected mice, are consistent with a "peripheral sink" mechanism of CNS plaque removal. In contrast, $A \beta$ levels were similar across the groups treated with the anti-pGlu-3 $A \beta$ mAbs and PBS controls suggesting that the anti-pGlu-3 A $\beta$ mAbs work through an alternative mechanism to remove $A \beta$ from the brain - a conclusion which is also supported by the increased CD68 staining. The significant contribution of the peripheral sink mechanism in case of 3A1 might also explain the low level of $A \beta$ reduction in our ex vivo phagocytosis assay.

While a different mode of action might contribute to the differential results obtained with 3A1, 07/1, 07/2a, and $07 / 2 \mathrm{a}-\mathrm{k}$, also the brain penetration of the drug may be of importance. Penetrance of peripherally administered antibodies into the brain remains a challenge of immunotherapy treatment with typically only approximately $0.1 \%$ of antibodies are thought to cross the blood brain barrier (BBB) into the CNS [55]. Our immunohistochemical data with only secondary antibodies demonstrated target engagement of 3A1,07/1, and 07/2a with plaques in the brain. In the $07 / 2 a$-treated mice, we saw $\sim 1.7 \times$ increase in concentration of pGlu-3 A $\beta$ IgG2a in brain homogenates compared with levels of pGlu-3A $\beta$ IgG1 in the mice treated with $07 / 1 \mathrm{mAb}$. 07/2a mAb may have better accessibility into the brain compared with $07 / 1$ resulting in better treatment outcomes. In agreement with other studies, we did not detect pGlu-3 $A \beta$ in the plasma of any of the mice in this study [12, 56, 57]; therefore, $07 / 1$ and $07 / 2 \mathrm{a}$ mAbs could not have been saturated in the periphery, unlike the $3 \mathrm{~A} 1 \mathrm{mAb}$, and as such provided better ability to work through a CNS-mediated process. Accordingly, $3 \mathrm{~A} 1$ concentration in the brain homogenate was much lower compared to $07 / 1$. The half-lives of murine IgG isotypes, IgG1, and IgG2a have been shown to be similar (6-8 days) [58].

Taken together, our results suggest that a strong effector function and stimulation of phagocytosis is required for pGlu3-A $\beta$ antibodies under consideration for a therapeutic trial. With amyloid immunotherapy trials being dampened by reports of ARIA, it is becoming more important to consider effector function. It was thought that Fc effector function could be a prominent contributor to the vascular side effects observed in clinical trials; therefore, AC immune developed crenezumab (licensed by Genentech), which is a humanized anti-A $\beta$ $m A b$ that binds multiple forms of $A \beta$ and is designed as an IgG4 isotype to limit inflammatory cytokine release while keeping phagocytic function [59]. However, disappointing results from trials were observed and further analyses using a murine-generated IgG2a equivalent of crenezumab provided evidence that in the absence of side effects, the ability of the antibody to engage plaques is also important to ensure a therapeutic effect [60]. This would suggest that effector function alone is not solely important when developing a treatment and requires intense consideration for every antibody showing different specificity. In addition to the eminent role of the effector function, our comparison with 3A1, an antibody detecting the intact $A \beta N$-terminus which does not recognize APP, clearly suggests that the specificity of the antibody epitope influences the mode of action and, possibly, the distribution to the brain.

Although aducanumab showed clinical benefit in a Phase III clinical trial in patients with mild cognitive impairment or early stages of $\mathrm{AD}$, and donanemab cleared plaques in Phase $1 \mathrm{a} / \mathrm{b}$ trials, both antibodies induced vasogenic edema visualized by MRI as ARIA-E. Therefore, from a translational perspective, a strong effector function in addition to a good $A \beta$ target in the absence of inducing inflammation is important for a therapeutic effect in patients. In order to meet these criteria, we introduced a CDC point mutation to $07 / 2$ a. Our data from ex vivo phagocytosis assays, the interaction profile with $\mathrm{Fcy}$ receptors in vitro and the treatment of double transgenic mice suggest that the effector function to elicit phagocytosis was largely conserved. Importantly, the brain inflammatory changes due to treatment with the CDC-mutant antibody were significantly reduced compared with the IgG2a antibody as analyzed by ${ }^{18} \mathrm{~F}$-GE180 
uptake. Thus, using an antibody like this may be useful for tackling ARIA observed in human clinical trials. Further nonclinical immunotherapy studies are currently underway to investigate this antibody further and to examine such in vivo effects.

\section{Conclusions}

Overall, we found that reduction of cognitive deficits and cerebral plaque load were associated with strong effector function of a murine anti-pGlu-3 $\mathrm{A} \beta \mathrm{mAb}$ in aged, plaquerich APP/PS1dE9 mice. Antibody engineering to reduce CDC-mediated complement binding facilitated plaque clearance and led to the reduction of neuroinflammation in vivo. Hence, our results suggest that targeting pathogenic pGlu-3 $A \beta$ and tailoring the effector function of humanized antibodies may be useful for modulating the phagocytic clearance and attenuating the neuroinflammatory response. The murine anti-pGlu3 A 3 IgG2a (07/2a) and IgG2a-k (07/ $2 \mathrm{a}-\mathrm{k}) \mathrm{mAbs}$ have been humanized and de-immunized for clinical development and their characterization is under review for publication.

\section{Supplementary information}

The online version of this article (https://doi.org/10.1186/s13195-019-0579-8) contains supplementary material, which is available to authorized users.

Additional file 1: Supplemental online material

\section{Abbreviations}

AD: Alzheimer's disease; ADCC: Antibody-dependent cellular toxicity; ARIA: Amyloid-related imaging abnormalities; A $\beta$ : Amyloid-beta; BBB: Blood brain barrier; CDC: Complement-dependent cytotoxicity; CFC: Contextual fear conditioning; CNS: Central nervous system; CTX: Cortex; DS: Down syndrome; HC: Hippocampus; i.p: Intraperitoneal; Ig: Immunoglobulin; IR: Immunoreactivity; PBS: Phosphate buffered saline; pGlu-3: Pyroglutamate-3; PMG: Primary microglia; Tg: Transgenic; TSPO: Translocator protein; Wt: Wildtype

\section{Acknowledgements}

We thank Drs. Shuyan Wang, Shipra Dubey, and Anthony Belanger (BWH) for assistance with the microPET imaging and Dr. Dennis Selkoe (BWH) for providing the R1282 antibody for $\mathrm{HC}$. General Electric provided the ${ }^{18} \mathrm{~F}$ GE180 PET tracer for purchase through a Material Transfer Agreement. Drs. Paola Ricciardi-Castagnoli (Toscana Life Sciences Foundation) and Joseph El Khoury (MGH) are thanked for providing the N9 cell line. Lastly, Vivoryon Therapeutics AG is thanked for providing the anti-pGlu3 mAbs used in this study as a gift-in-kind.

\section{Funding}

This work was funded by the National Institutes of Health, NIH/NIA RO1 AG040092 and NIH/NIA RF1 AG058657 to CAL.

\section{Availability of data and materials}

The datasets generated and/or analyzed during the current study are available from the corresponding author on reasonable request.

\section{Authors' contributions}

HC, SS, and CAL designed the experiments. SS and CAL critically revised the manuscript. HC performed and analyzed the in vivo and ex vivo experiments (except PET imaging and behavior) and wrote the manuscript. BC performed the behavioral testing. $\mathrm{BL}, \mathrm{KL}, \mathrm{MAP}$, and MDC performed the in vivo microPET imaging. BL analyzed the in vivo microPET imaging and contributed to the writing of the manuscript. JF bred the APP/PS1 and Wt mice and performed genotyping. BON generated and characterized the $3 \mathrm{~A} 1$
mAb. MK, TH, JUR, and SS generated and characterized the anti-pGlu3 mAbs. All authors read and approved the final manuscript.

\section{Ethics approval and consent to participate}

Animal studies performed in the Lemere Lab were approved by the Harvard Standing Committee for Animal Use and was in compliance with all state and federal regulations. The Harvard Medical School animal management program is accredited by the Association for the Assessment and Accreditation of Laboratory Animal Care International (AALAC) and meets all National Institutes of Health standards as demonstrated by an approved Assurance of Compliance (A3431-01) filed at the Office of Laboratory Animal Welfare. Animal studies performed at the AAALAC-accredited QPS Austria $\mathrm{GmbH}$ site conformed to the Austrian guidelines for the care and use of laboratory animals and were approved by the Styrian government, Austria.

\section{Consent for publication}

Not applicable.

\section{Competing interests}

According to the journal's requirements, we hereby declare that Martin Kleinschmidt, Jens-Ulrich Rahfeld, Stephan Schilling, and Inge Lues are former and Thore Hettmann, present, employees of Vivoryon Therapeutics AG, Germany and hold stock options of the company. Jens-Ulrich Rahfeld and Stephan Schilling are advisors to Vivoryon Therapeutics AG. Senior author, Cynthia A. Lemere, was an unpaid scientific advisory board member for Vivoryon Therapeutics AG, receives antibodies, and has previously received unrestricted funding from Vivoryon Therapeutics AG for some of her past work on pGlu-3 A immunotherapy. She has also served as a consultant to Biogen.

\section{Author details}

${ }^{1}$ Ann Romney Center for Neurologic Diseases, Brigham and Women's Hospital, Hale BTM 9002S, 60 Fenwood Rd, Boston, MA 02115, USA. ${ }^{2}$ Harvard Medical School, Boston, MA, USA. ${ }^{3}$ Vivoryon Therapeutics AG, Halle (Saale), Germany. ${ }^{4}$ Department Drug Design and Target Validation, Fraunhofer Institute for Cell Therapy and Immunology, Halle (Saale), Germany. ${ }^{5}$ Mouse Behavior Core, Harvard Medical School, Boston, MA, USA. ${ }^{6}$ QPS Austria, Grambach, Austria. 'Department of Radiology, Brigham Women's Hospital, Boston, MA, USA.

Received: 23 October 2019 Accepted: 30 December 2019

Published online: 13 January 2020

\section{References}

1. World Alzheimer Report 2019. Attitudes to dementia. London: Alzheimer's Disease International; 2019.

2. Hardy J, Selkoe DJ. The amyloid hypothesis of Alzheimer's disease: progress and problems on the road to therapeutics. Science. 2002;297(5580):353-6.

3. Lemere CA, Masliah E. Can Alzheimer disease be prevented by amyloid-beta immunotherapy? Nat Rev Neurol. 2010;6(2):108-19.

4. DeMattos RB, Bales KR, Cummins DJ, Dodart JC, Paul SM, Holtzman DM. Peripheral anti-A beta antibody alters CNS and plasma A beta clearance and decreases brain A beta burden in a mouse model of Alzheimer's disease. Proc Natl Acad Sci U S A. 2001;98(15):8850-5.

5. Bard F, Cannon C, Barbour R, Burke RL, Games D, Grajeda H, Guido T, Hu K, Huang J, Johnson-Wood K, et al. Peripherally administered antibodies against amyloid beta-peptide enter the central nervous system and reduce pathology in a mouse model of Alzheimer disease. Nat Med. 2000;6(8):916-9.

6. Sevigny J, Chiao P, Bussiere T, Weinreb PH, Williams L, Maier M, Dunstan R, Salloway $S$, Chen T, Ling Y, et al. The antibody aducanumab reduces Abeta plaques in Alzheimer's disease. Nature. 2016;537(7618):50-6.

7. Vidarsson $G$, Dekkers $G$, Rispens T. IgG subclasses and allotypes: from structure to effector functions. Front Immunol. 2014:5:520.

8. Kapur R, Einarsdottir HK, Vidarsson G. IgG-effector functions: "the good, the bad and the ugly". Immunol Lett. 2014;160(2):139-44.

9. Alyanakian MA, Bernatowska E, Scherrmann JM, Aucouturier P, Poplavsky JL. Pharmacokinetics of total immunoglobulin $\mathrm{G}$ and immunoglobulin $\mathrm{G}$ subclasses in patients undergoing replacement therapy for primary immunodeficiency syndromes. Vox Sang. 2003;84(3):188-92.

10. Salfeld JG. Isotype selection in antibody engineering. Nat Biotechnol. 2007;25(12):1369-72. 
11. Cummings JL, Cohen S, van Dyck CH, Brody M, Curtis C, Cho W, Ward M, Friesenhahn M, Rabe C, Brunstein F, et al. ABBY: a phase 2 randomized tria of crenezumab in mild to moderate Alzheimer disease. Neurology. 2018; 90(21):e1889-97.

12. Frost $\mathrm{L}$, Liu B, Rahfeld JU, Kleinschmidt M, O'Nuallain B, Le KX, Lues I, Caldarone BJ, Schilling S, Demuth HU, et al. An anti-pyroglutamate-3 Abeta vaccine reduces plaques and improves cognition in APPswe/PS1DeltaE9 mice. Neurobiol Aging. 2015;36(12):3187-99.

13. Harigaya Y, Saido TC, Eckman CB, Prada CM, Shoji M, Younkin SG. Amyloid beta protein starting pyroglutamate at position 3 is a major component of the amyloid deposits in the Alzheimer's disease brain. Biochem Biophys Res Commun. 2000;276(2):422-7.

14. Saido TC, Iwatsubo T, Mann DM, Shimada H, Ihara Y, Kawashima S. Dominant and differential deposition of distinct beta-amyloid peptide species, A beta N3(pE), in senile plaques. Neuron. 1995;14(2):457-66.

15. Wirths $\mathrm{O}$, Breyhan $\mathrm{H}$, Cynis $\mathrm{H}$, Schilling S, Demuth HU, Bayer TA Intraneuronal pyroglutamate-Abeta 3-42 triggers neurodegeneration and lethal neurological deficits in a transgenic mouse model. Acta Neuropathol. 2009:118(4):487-96.

16. Frost $J$, Le KX, Cynis H, Ekpo E, Kleinschmidt M, Palmour RM, Ervin FR, Snigdha S, Cotman CW, Saido TC, et al. Pyroglutamate-3 amyloid-beta deposition in the brains of humans, non-human primates, canines, and Alzheimer disease-like transgenic mouse models. Am J Pathol. 2013;183(2): 369-81.

17. Grochowska KM, Yuanxiang P, Bar J, Raman R, Brugal G, Sahu G, Schweizer M, Bikbaev A, Schilling S, Demuth HU, et al. Posttranslational modification impact on the mechanism by which amyloid-beta induces synaptic dysfunction. EMBO Rep. 2017;18(6):962-81.

18. He W, Barrow CJ. The A beta 3-pyroglutamyl and 11-pyroglutamyl peptides found in senile plaque have greater beta-sheet forming and aggregation propensities in vitro than full-length A beta. Biochemistry. 1999;38(33): 10871-7.

19. Nussbaum JM, Schilling S, Cynis H, Silva A, Swanson E, Wangsanut T, Tayler K, Wiltgen B, Hatami A, Ronicke R, et al. Prion-like behaviour and taudependent cytotoxicity of pyroglutamylated amyloid-beta. Nature. 2012; 485(7400):651-5

20. Schilling S, Lauber T, Schaupp M, Manhart S, Scheel E, Bohm G, Demuth HU On the seeding and oligomerization of pGlu-amyloid peptides (in vitro). Biochemistry. 2006;45(41):12393-9.

21. Schlenzig D, Manhart S, Cinar Y, Kleinschmidt M, Hause G, Willbold D, Funke SA, Schilling S, Demuth HU. Pyroglutamate formation influences solubility and amyloidogenicity of amyloid peptides. Biochemistry. 2009;48(29):7072-8.

22. Schlenzig D, Ronicke R, Cynis H, Ludwig HH, Scheel E, Reymann K, Saido T, Hause G, Schilling S, Demuth HU. N-terminal pyroglutamate formation of Abeta38 and Abeta40 enforces oligomer formation and potency to disrupt hippocampal long-term potentiation. J Neurochem. 2012;121(5):774-84.

23. Hussain R, Dawood G, Abrar N, Toossi Z, Minai A, Dojki M, Ellner JJ. Selective increases in antibody isotypes and immunoglobulin $G$ subclass responses to secreted antigens in tuberculosis patients and healthy household contacts of the patients. Clin Diagn Lab Immunol. 1995;2(6):726-32.

24. Frost JL, Liu B, Kleinschmidt M, Schilling S, Demuth HU, Lemere CA. Passive immunization against pyroglutamate-3 amyloid-beta reduces plaque burden in Alzheimer-like transgenic mice: a pilot study. Neurodegener Dis. 2012;10(1-4):265-70.

25. Liu B, Le KX, Park MA, Wang S, Belanger AP, Dubey S, Frost JL, Holton P, Reiser $V$, Jones PA, et al. In vivo detection of age- and disease-related increases in neuroinflammation by 18F-GE180 TSPO microPET imaging in wild-type and Alzheimer's transgenic mice. J Neurosci. 2015;35(47):15716-30.

26. Wadsworth $\mathrm{H}$, Jones PA, Chau WF, Durrant C, Fouladi N, Passmore J, O'Shea D, Wynn D, Morisson-Iveson V, Ewan A, et al. [(1)(8)F]GE-180: a novel fluorine-18 labelled PET tracer for imaging translocator protein $18 \mathrm{kDa}$ (TSPO). Bioorg Med Chem Lett. 2012;22(3):1308-13.

27. Jankowsky JL, Fadale DJ, Anderson J, Xu GM, Gonzales V, Jenkins NA, Copeland NG, Lee MK, Younkin LH, Wagner SL, et al. Mutant presenilins specifically elevate the levels of the 42 residue beta-amyloid peptide in vivo: evidence for augmentation of a 42-specific gamma secretase. Hum Mol Genet. 2004;13(2):159-70

28. Liu B, Frost JL, Sun J, Fu H, Grimes S, Blackburn P, Lemere CA. MER5101, a novel Abeta1-15:DT conjugate vaccine, generates a robust anti-Abeta antibody response and attenuates Abeta pathology and cognitive deficits in APPswe/PS1DeltaE9 transgenic mice. J Neurosci. 2013;33(16):7027-37.
29. Giulian D, Baker TJ. Characterization of ameboid microglia isolated from developing mammalian brain. J Neurosci. 1986;6(8):2163-78.

30. Fu H, Liu B, Frost JL, Hong S, Jin M, Ostaszewski B, Shankar GM, Costantino IM, Carroll MC, Mayadas TN, et al. Complement component C3 and complement receptor type 3 contribute to the phagocytosis and clearance of fibrillar Abeta by microglia. Glia. 2012;60(6):993-1003.

31. Righi M, Mori L, De Libero G, Sironi M, Biondi A, Mantovani A, Donini SD, Ricciardi-Castagnoli P. Monokine production by microglial cell clones. Eur J Immunol. 1989;19(8):1443-8.

32. Demattos RB, Lu J, Tang Y, Racke MM, Delong CA, Tzaferis JA, Hole JT, Forster BM, McDonnell PC, Liu F, et al. A plaque-specific antibody clears existing beta-amyloid plaques in Alzheimer's disease mice. Neuron. 2012; 76(5):908-20.

33. Pfeifer M, Boncristiano S, Bondolfi L, Stalder A, Deller T, Staufenbiel M, Mathews PM, Jucker M. Cerebral hemorrhage after passive anti-Abeta immunotherapy. Science. 2002;298(5597):1379.

34. Wilcock DM, Rojiani A, Rosenthal A, Subbarao S, Freeman MJ, Gordon MN Morgan D. Passive immunotherapy against Abeta in aged APP-transgenic mice reverses cognitive deficits and depletes parenchymal amyloid deposits in spite of increased vascular amyloid and microhemorrhage. J Neuroinflammation. 2004;1(1):24.

35. Racke MM, Boone LI, Hepburn DL, Parsadainian M, Bryan MT, Ness DK, Piroozi KS, Jordan WH, Brown DD, Hoffman WP, et al. Exacerbation of cerebral amyloid angiopathy-associated microhemorrhage in amyloid precursor protein transgenic mice by immunotherapy is dependent on antibody recognition of deposited forms of amyloid beta. J Neurosci. 2005; 25(3):629-36.

36. Lemere CA, Spooner ET, LaFrancois J, Malester B, Mori C, Leverone JF, Matsuoka Y, Taylor JW, DeMattos RB, Holtzman DM, et al. Evidence for peripheral clearance of cerebral Abeta protein following chronic, active Abeta immunization in PSAPP mice. Neurobiol Dis. 2003;14(1):10-8.

37. Gillman AL, Jang H, Lee J, Ramachandran S, Kagan BL, Nussinov R, Teran Arce F. Activity and architecture of pyroglutamate-modified amyloid-beta (AbetapE3-42) pores. J Phys Chem B. 2014;118(26):7335-44.

38. Matos JO, Goldblatt G, Jeon J, Chen B, Tatulian SA. Pyroglutamylated amyloid-beta peptide reverses cross beta-sheets by a prion-like mechanism. J Phys Chem B. 2014;118(21):5637-43.

39. Lues I, Weber F, Meyer A, Bühring U, Hoffmann T, Kühn-Wache K, Manhart S, Heiser U, Pokorny R, Chiesa J, et al. A phase 1 study to evaluate the safety and pharmacokinetics of PQ912, a glutaminyl cyclase inhibitor, in healthy subjects. Alzheimer's and Dementia. 2015;1(3):182-95.

40. Wirths O, Erck C, Martens H, Harmeier A, Geumann C, Jawhar S, Kumar S, Multhaup G, Walter J, Ingelsson M, et al. Identification of low molecular weight pyroglutamate a \{beta\} oligomers in Alzheimer disease: a novel tool for therapy and diagnosis. J Biol Chem. 2010;285(53):41517-24.

41. McGeer PL, Itagaki S, Tago H, McGeer EG. Reactive microglia in patients with senile dementia of the Alzheimer type are positive for the histocompatibility glycoprotein HLA-DR. Neurosci Lett. 1987;79(1-2):195-200.

42. El Khoury J, Toft M, Hickman SE, Means TK, Terada K, Geula C, Luster AD. $\mathrm{C} c r 2$ deficiency impairs microglial accumulation and accelerates progression of Alzheimer-like disease. Nat Med. 2007;13(4):432-8.

43. Lambert JC, Heath S, Even G, Campion D, Sleegers K, Hiltunen M, Combarros O, Zelenika D, Bullido MJ, Tavernier B, et al. Genome-wide association study identifies variants at CLU and CR1 associated with Alzheimer's disease. Nat Genet. 2009;41(10):1094-9.

44. Guerreiro R, Wojtas A, Bras J, Carrasquillo M, Rogaeva E, Majounie E, Cruchaga C, Sassi C, Kauwe JS, Younkin S, et al. TREM2 variants in Alzheimer's disease. N Engl J Med. 2013;368(2):117-27.

45. Wang Y, Cella M, Mallinson K, Ulrich JD, Young KL, Robinette ML, Gilfillan S, Krishnan GM, Sudhakar S, Zinselmeyer BH, et al. TREM2 lipid sensing sustains the microglial response in an Alzheimer's disease model. Cell. 2015;160(6):1061-71.

46. Crehan $\mathrm{H}$, Hardy J, Pocock J. Blockage of CR1 prevents activation of rodent microglia. Neurobiol Dis. 2013;54:139-49.

47. Ravetch JV, Bolland S. IgG Fc receptors. Annu Rev Immunol. 2001;19:275-90.

48. Black RS, Sperling RA, Safirstein B, Motter RN, Pallay A, Nichols A, Grundman M. A single ascending dose study of bapineuzumab in patients with Alzheimer disease. Alzheimer Dis Assoc Disord. 2010;24(2):198-203.

49. Ostrowitzki S, Deptula D, Thurfjell L, Barkhof F, Bohrmann B, Brooks DJ, Klunk WE, Ashford E, Yoo K, Xu ZX, et al. Mechanism of amyloid removal in patients with Alzheimer disease treated with gantenerumab. Arch Neurol. 2012;69(2):198-207. 
50. Li Q, Lebson L, Lee DC, Nash K, Grimm J, Rosenthal A, Selenica ML, Morgan D, Gordon MN. Chronological age impacts immunotherapy and monocyte uptake independent of amyloid load. J Neurolmmune Pharmacol. 2012;7(1): 202-14.

51. Solomon B, Koppel R, Frankel D, Hanan-Aharon E. Disaggregation of Alzheimer beta-amyloid by site-directed mAb. Proc Natl Acad Sci U S A. 1997;94(8):4109-12.

52. Wilcock DM, DiCarlo G, Henderson D, Jackson J, Clarke K, Ugen KE, Gordon MN, Morgan D. Intracranially administered anti-Abeta antibodies reduce beta-amyloid deposition by mechanisms both independent of and associated with microglial activation. J Neurosci. 2003;23(9):3745-51.

53. Wilcock DM, Gordon MN, Ugen KE, Gottschall PE, DiCarlo G, Dickey C, Boyett KW, Jantzen PT, Connor KE, Melachrino J, et al. Number of Abeta inoculations in APP+PS1 transgenic mice influences antibody titers, microglial activation, and congophilic plaque levels. DNA Cell Biol. 2001;20(11):731-6.

54. Schenk D, Barbour R, Dunn W, Gordon G, Grajeda H, Guido T, Hu K, Huang J, Johnson-Wood K, Khan K, et al. Immunization with amyloid-beta attenuates Alzheimer-disease-like pathology in the PDAPP mouse. Nature. 1999;400(6740):173-7.

55. Banks WA, Terrell B, Farr SA, Robinson SM, Nonaka N, Morley JE. Passage of amyloid beta protein antibody across the blood-brain barrier in a mouse model of Alzheimer's disease. Peptides. 2002;23(12):2223-6.

56. Golde TE, Das P, Levites Y. Quantitative and mechanistic studies of Abeta immunotherapy. CNS Neurol Disord Drug Targets. 2009;8(1):31-49.

57. Seubert $P$, Barbour R, Khan K, Motter R, Tang P, Kholodenko D, Kling K, Schenk D, Johnson-Wood K, Schroeter S, et al. Antibody capture of soluble Abeta does not reduce cortical Abeta amyloidosis in the PDAPP mouse. Neurodegener Dis. 2008;5(2):65-71.

58. Vieira P, Rajewsky K. The half-lives of serum immunoglobulins in adult mice. Eur J Immunol. 1988;18(2):313-6.

59. Adolfsson O, Pihlgren M, Toni N, Varisco Y, Buccarello AL, Antoniello K, Lohmann S, Piorkowska K, Gafner V, Atwal JK, et al. An effector-reduced anti-beta-amyloid (Abeta) antibody with unique abeta binding properties promotes neuroprotection and glial engulfment of Abeta. J Neurosci. 2012;32(28):9677-89.

60. Fuller JP, Stavenhagen JB, Christensen S, Kartberg F, Glennie MJ, Teeling JL. Comparing the efficacy and neuroinflammatory potential of three antiabeta antibodies. Acta Neuropathol. 2015;130(5):699-711.

\section{Publisher's Note}

Springer Nature remains neutral with regard to jurisdictional claims in published maps and institutional affiliations.

\section{Ready to submit your research? Choose BMC and benefit from:}

- fast, convenient online submission

- thorough peer review by experienced researchers in your field

- rapid publication on acceptance

- support for research data, including large and complex data types

- gold Open Access which fosters wider collaboration and increased citations

- maximum visibility for your research: over $100 \mathrm{M}$ website views per year

At BMC, research is always in progress.

Learn more biomedcentral.com/submissions 